\title{
GRAVITY SURVEYING IN EARLY GEOPHYSICS. II. FROM MOUNTAINS TO SALT DOMES
}

\author{
RichaRD J. HOWARTH \\ Department of Earth Sciences, University College London, \\ Gower Street, London WC1E6BT, UK (r.howarth@ucl.ac.uk)
}

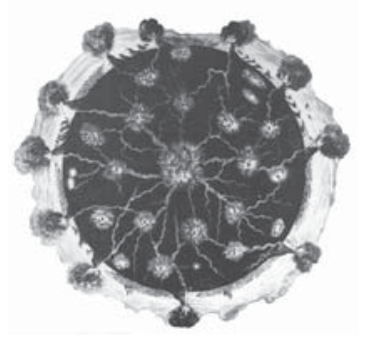

Earth Sciences History, v. 26 , no. 2,2007 , pp. 229-261.

\begin{abstract}
Progress in measurement of the force of gravity and its contribution to the understanding of geology, and to exploration for oil and mineral deposits, from the eighteenth to the early twentieth century is reviewed. Initially, work focused on determination of the mean density of the Earth. Pendulum observations during the trigonometric survey of India (1805-43) revealed a low-density zone beneath the Himalayas and led to development of the Pratt and Airy compensation models in 1855, followed by Dutton's concept of isostatic compensation in 1889. Use of the Eötvös torsion balance (1889) to map the gravity field over an oil-bearing structure in 1915-16 heralded economic applications. By the 1920s, it was being widely used to search for oil-bearing salt domes, coal and mineral deposits. With the introduction of the gravity meter in the 1930s, the torsion balance fell into disuse and the modern era of gravity surveying and prospecting began. With the development of progressively more sensitive instruments, the gravity meter has retained its place, becoming an essential companion to 3-D seismic surveys and, with new instrumentation, gradiometry has seen a revival as an extremely powerful exploration tool.
\end{abstract}

\section{INTRODUCTION}

Part I of this review (Howarth, 2007) described how following Isaac Newton's (1642-1727) postulate in 1686 that the Figure of the Earth was, like that of Jupiter, an oblate spheroid, and that both the force of gravity (indicated by the length of a pendulum beating seconds) and the length of a 1-degree arc of latitude $(\theta)$, should increase towards the poles as $\sin ^{2}(\theta)$. In 1737 his hypothesis was found, by measurement of arc lengths, to be correct. In 1743, Alexis Claude Clairaut (1713-1765) showed how to compute the amount of flattening of the Earth's spheroid from gravity measurements. By the early nineteenth century, acquisition of pendulum data from stations in many latitudes was enabling this characteristic to become increasingly well defined. However, occasional discrepant results were beginning to raise questions as to whether the nature of the substratum might, on occasion, influence the pendulum length measurements and statistical analysis of such data by Edward Sabine (1788-1883) and the English Astronomer Royal, George Biddell Airy (1801-1892) provided the first definite confirmation that this might be the case. 


\section{THE ATTRACTION OF MOUNTAINS}

The earliest practical investigations, which led to an indirect involvement with geology, were aimed at determining whether the attractive force exerted by the mass of a large mountain would be sufficient to deflect a plumb-line from the vertical. As the result of an oversight, Newton had underestimated this effect, concluding that "[a] mountain of an hemispherical figure, three miles high, and six broad, will not, by its attraction, draw the pendulum two minutes out of the true perpendicular." (Newton 1726, Sec. 22; Cajori, 1934, p.570). Nevertheless, early investigators were keen to test his assertion.

The first to do so were the French mathematician-astronomers, Pierre Bouguer (1698-1758) and Charles Marie de La Condamine (1701-1744) in December 1738, in the course of their measurement of the length of a three-degree equatorial arc across Peru and Ecuador. They chose to investigate the phenomenon at Chimboraço (Chimborazo, 6530 $\mathrm{m})$, in Ecuador, the highest mountain then known in the New World, which rises some $3600 \mathrm{~m}$ above the tablelands near Quito (Bouguer 1749, pp. 379-390). Bouguer's prior calculations indicated that the mountain's influence on a plumb-line might equal $1 / 1000$ th part of that of the whole world, and he therefore anticipated a deviation from the vertical of about 43 " of arc.

They investigated this by sighting on the meridian altitudes of a set of chosen stars. Ascending to within $425 \mathrm{~m}$ of the summit on the south side of Chimborazo and using an astronomical quadrant whose zenith was fixed by means of a plumb-line, they determined the meridian altitudes of six stars to the north of their station $\left(N_{1}\right)$, and of four to the south $\left(S_{1}\right)$. These observations were repeated on the following day. They then established a lower station, $1.8 \mathrm{~km}$ to the west and $90 \mathrm{~m}$ lower than the first, and repeated the entire set of observations $\left(N_{2}, S_{2}\right)$. It was assumed that the observed altitudes measured at the first station would include the deflection $(\tau)$ of the plumb-line towards the mountain plus an error component $(\varepsilon)$, whereas those from the more distant station would only contain the error component. The overall mean of the observed differences $\left[\left(N_{1}-\tau+\varepsilon\right)-\left(N_{2}+\varepsilon\right)\right]$ between the six individual mean altitudes of the set of northerly stars at the two stations was 1' 19"; while for the four southerly stars, the mean of the differences $\left[\left(S_{1}+\tau+\varepsilon\right)\right.$ $\left(S_{2}+\varepsilon\right)$ ] was 1' 34 ". Then, assuming that the observational errors were of similar magnitude and cancelled out: $\tau=\left[\left(S_{1}-S_{2}\right)-\left(N_{1}-N_{2}\right)\right] / 2$, i.e. 7.5" of arc (Bouguer 1749, p. 388).

In considering the interpretation of his pendulum observations, Bouguer (1749, pp. 359-361) took into account both the effect caused by the elevation of the station at Quito above sea level, and the density of the matter forming the mountain chain in which it was situated relative to the density of the entire Earth. Setting $h$ as the station height above sea level; $R$ the radius of the Earth at that latitude; $\delta$ the density of matter lying above sea level; and $\Delta$ the density of the whole Earth; he considered the effect of having a spherical shell around the Earth above sea level, of thickness $h$ and density $\delta$, on the intensity of gravity at Quito, as well as that of the geometry of a mountain chain with a cross section like that of "the roof of a house" and of infinite length (p. 361), he deduced (p. 362) that since the intensity of gravity at sea level is $R \Delta$, and at Quito is $(R-2 h) \Delta+3 R \delta / 2$, the difference between them is $2 h \Delta-3 R \delta / 2$.

Since he had found a diminution of $1 / 1331$ in the length of the pendulum on ascending from sea level to Quito, Bouguer stated that the ratio $(2 h \Delta-3 h \delta / 2) / R \Delta$ must 
be equal to this value. However, at Quito $h / R=1 / 2337$, hence $(1 / 2337)[2 \Delta-3 \delta / 2] / \Delta=$ $1 / 1331$, from which $\delta=(850 / 3993) \Delta$, i.e. $0.21 \Delta$. This suggested that "the Cordillera of Peru, despite all the metallic materials which it contains, is not a quarter of the density of the interior of the Earth" (p. 362). Bouguer (p. 389) admitted that since little was known about the density of the Earth, the density of mountains might be much different to what was believed. The fact that Chimborazo (like several of the other mountains) appeared to have been a volcano in the past, and that one of its mouths could be seen on its northnorth-west side, might mean it was less massive than had been supposed, thus accounting for the fact that the deflection of the pendulum which it caused was much smaller than had been expected. Nevertheless, he was quite certain that those who thought that the middle of the Earth contained a large void beneath a thin crust or, as suggested by "Wodward" it was filled with water (perhaps a reference to Woodward 1723), were equally wrong. Bouguer (1749, p. 363) concluded that the Earth must become much more compact (dense) towards its centre and that there must be a change in its density from that of the rocks at the surface at a certain depth and that it must be "very considerable."

In 1772 the Astronomer Royal for England, Nevil Maskelyne (1732-1811) suggested, perhaps at the behest of the physicist Henry Cavendish (1731-1810) (Howse 1990, p. 131), that a similar investigation of the gravitational attraction of a mountain should be undertaken in the British Isles (Maskelyne 1775a). A committee of the Royal Society eventually recommended that Schehallien ( $1010 \mathrm{~m}$; today spelt Schiehallion) in Perthshire, Scotland, would be the most suitable site for the investigation. Consequently, in the early summer of 1774, Maskelyne's assistant, the mathematician Reuben Burrow (17471792), accompanied by a surveyor, established two stations in the same meridian but lying to the north and south of the summit of Schiehallion, and respectively $440 \mathrm{~m}$ and $360 \mathrm{~m}$ below it (this was an improvement on Bouguer's investigation, which relied on two stations on the same side of Chimborazo).

Maskelyne had originally intended to leave the experiment to Burrow but, at the insistence of the Royal Society, he reluctantly travelled up to Scotland to make the observations himself. Between July and October 1774, he took sightings of forty-three stars from each station. These gave a mean difference of 54.6" of arc between their latitudes, whereas a triangulated ground survey (carried out in 1774-6) showed 42.9". The effect of "the two contrary attractions of the hill" on the plumb-line was therefore to cause an 11.6" difference between the two sets of results (Maskelyne, 1775b, p. 531) from which he estimated that "the density of the hill is about half the mean density of the [E]arth" (Maskelyne, 1775b, p. 532). This was a greater contrast than Bouguer had obtained; the implications of Maskelyne's, admittedly tentative, result were clear:

The mean density of the earth is at least double of that at the surface, and consequently, that the density of the internal parts of the earth is much greater than near the surface. Hence also, the whole quantity of matter in the earth will be at least as great again as if it had been all composed of matter of the same density with that at the surface; or will be about four or five times as great as if it were all composed of water. The idea thus afforded us, from this experiment, is totally contrary to the hypothesis of some naturalists, who suppose the [E] arth to be only a great hollow shell of matter; supporting itself from the property of an arch, with an immense vacuity in the midst of it. (Maskelyne, 1775b, p. 533).

Both Maskelyne, and Bouguer before him, allude to followers of a 'hollow earth' model; such ideas can be traced back to Halley (1692).

Nevertheless, concerned that the "figure and dimensions of the hill" ought really to have been taken into account, Maskelyne enlisted the help of the English mathematician, 


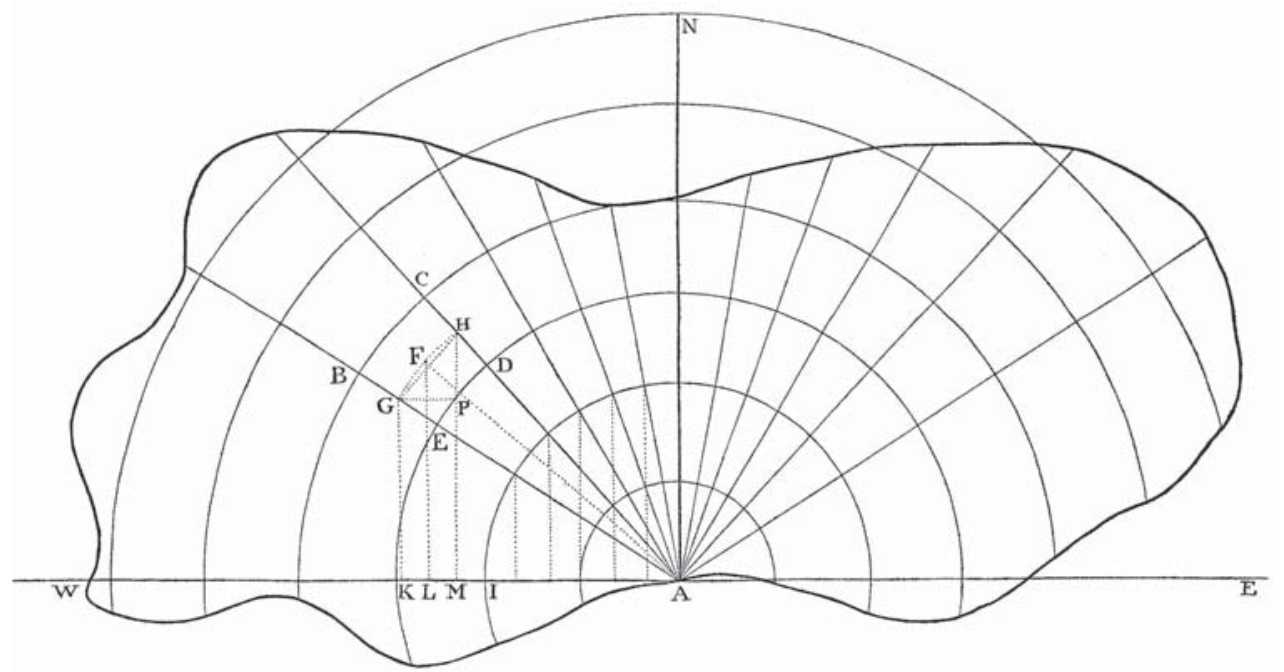

Figure 1. Hutton's illustration of his method for subdivision of the terrain in order to "calculate the attraction of the matter above the plane" at the North and South observatories on Schiehallion. He used 20 rings with each quadrant divided into 12 sectors. A is the observatory; AN the meridian; WE the west-east line. (Hutton 1779, Fig. 1, Plate X).

Charles Hutton (1737-1823) to improve his analysis. Using ideas of his own and "hints" from Cavendish (Hutton 1779, p. 750), Hutton decided it was necessary to calculate the attraction of the mountain on the plum-bob at the two stations as exactly as possible:

$[T]$ he best method was to divide the plan into a great number of small parts, which may be considered as the bases of as many vertical columns or pillars of matter into which the hill and the adjacent ground may be supposed to be divided by vertical planes, forming an imaginary group of vertical columns, something like a set of basaltine pillars, or like the cells in a piece of honey-comb [Figure 1]; then to compute the attraction of each pillar separately in the direction of the meridian; and lastly, to take the sum of all these computed effects for the whole attraction of the matter in the hill (Hutton 1779, p. 748).

In order to better estimate the mean height of the top of each cell, Hutton interpolated from the detailed topographic survey of the mountain. Then, with the aid of some computational short-cuts, suggested to him by Cavendish (Hutton 1779, p. 766), and the assumptions that: (i) the mountain's density was uniform and (ii) unit volume at unit distance had unit attraction, he arrived at topographically-corrected estimates of the attraction at the two stations. Then, assuming that "the density of matter in the hill is equal to the mean density of that in the whole Earth" (Hutton 1779, p. 782), he argued that the ratio of the total attraction of the hill $(8811 \mathrm{ft})$ to that of the Earth is $8811 / 87522720=$ $1 / 9933$. The denominator is the attraction of a sphere on a body at its surface, which is $(2 / 3) \pi D=(2 / 3) c ; \pi$ is the circumference of a circle of unit diameter; $D$ is the diameter of the Earth; and $c$ is its circumference (in English feet).

The astronomical observations suggested that the ratio was in the proportion of unit radius to $\tan \left(11.6^{\prime \prime}\right)$, the observed deviation of the pendulum, i.e. 1:0.00005624 or $1 / 17781$ and "after allowing for the centrifugal force arising from the rotation of the Earth about its axis" (Hutton 1779, p. 780) this became 1/17804. Since the terrestrially-based ratio was computed on the assumption of equal density of the material forming the mountain and the main body of the Earth, this suggested that the mean density of the Earth 
exceeded that of the hill by (17804/9933), i.e. it was 1.79 times denser than the rocks forming the mountain. Realising that the best estimate of the latter could only be had by means of many samples obtained by boring into the mountain "after the manner that is practiced in boring holes to the coal mines from the surface of the ground" (Hutton 1779, p. 782), which was impractical, he took as his best estimate the density of "common stone" $2.5\left[\mathrm{gm} \mathrm{cm}^{-3}\right]$, and so obtained a final value for the Earth's mean density of "about" $4.5\left[\mathrm{gm} \mathrm{cm}^{-3}\right]$ (Hutton 1779, pp. 780-783), which lay in the centre of Maskelyne's previous estimate.

However, the potential for error in assuming the density of the mountain was simply that of "common stone" troubled both Hutton and Maskelyne, so they approached the Edinburgh mathematician, physicist and geologist, John Playfair (1748-1819), who had previously visited Maskelyne in the field. As a result, Playfair, accompanied by his friend Lord Webb Seymour (1777-1819), undertook what he styled a "Mineralogical" or "Lithological" Survey of Schiehallion in June 1801.

After some considerable difficulty, they located the sites formerly occupied by the control point cairns for Maskelyne's 1774 survey, and carried out a systematic geological examination of the mountain. The exact locations from which they collected thirteen specimens of "granular quartz", ten of "mica and hornblend[e] slate" and five of "granular limestone," were each carefully determined by triangulation. They measured the specific gravity of each specimen and calculated the mean for each lithology: 2.64, 2.83 and 2.77 respectively. The last two were felt to be sufficiently similar that they could be grouped together for the purpose of further calculation (Playfair 1811, p. 363).

Having realised that Hutton's methods had to be adapted to a situation in which nonuniform density distributions existed, before tackling the practical problem, Playfair first developed several theoretical models for "solids of greatest attraction," calculating the dimensions of various geometric solids which would cause the gravitational attraction on a particle lying at a given position on their surface to be a maximum (Playfair 1812). He derived solutions for a right circular cylinder, half-cylinder, right circular cone, rod of finite length, rectangular lamina, parallelepiped, etc. However, it was his result for the half-cylinder which came in particularly useful in his reanalysis of Hutton's earlier work, and when calculating the attraction, Playfair carefully allocated the observed proportions of each of the "quartzy" and "micaceous" rocks to the appropriate cells of Hutton's prismatic net.

Playfair and Webb Seymour had traced out the boundary between the quartzose and schistose rocks, finding the former appeared to occupy only the higher part of the mountain (above the level of Maskelyne's north and south stations), but such was the state of geological knowledge at that time, they could not decide whether the quartzose rocks represented the top of a vertical "cylinder" (as in Hutton's interpretation) or crossed the mountain horizontally. Consequently, Playfair (1811) repeated Hutton's calculations for both cases, arriving at values of 4.56 and $4.87\left[\mathrm{gm} \mathrm{cm}^{-3}\right]$ for the mean density of the Earth, depending on which geological model was to be preferred. Significantly, criticism in a French-language synopsis of Maskelyne's paper (Leroy 1776) swept away whatever vestiges of credibility still clung to the last of those who denied the reality of Newton's theory of gravitational attraction and his view of the Figure of the World (Evans 1996).

The investigations on Chimborazo and Schiehallion heralded many subsequent determinations of the mean density of the Earth. Airy and the Austrian military officer, Major Robert (Freiherr von Daublebsky) von Sterneck (1839-1910) found the mean density by swinging pairs of chronometrically-linked pendulums at the top and bottom 
of deep mine shafts in County Durham, England (Airy 1856a, b); Príbram, Bohemia, now in the Czech Republic (Sterneck 1882, 1883); and Freiburg, Germany (Sterneck 1885). However, the majority of determinations were laboratory-based (see Poynting 1894 and Bullen 1975 for discussion). These depended on measurement of the universal gravitational constant, which began with the work of Cavendish (1798) and was eventually established as $6.66 \times 10^{-8} \mathrm{~cm}^{3} \mathrm{~g}^{-1} \mathrm{~s}^{-2}$, which fixed the average density as $5.52 \mathrm{gm} \mathrm{cm}^{-3}$ (Williamson and Adams 1923), a value which has remained essentially unchanged since.

During the nineteenth century there was a vigorous debate as to the nature of the interior of the Earth (see Brush 1979 and Kushner 1990, chapters 1-5, for discussion). Although it was suggested by the American geologist, James Dwight Dana (1813-1895) in 1875 that the Earth contained a rigid iron core surrounded by rock, real knowledge of its internal structure only became possible with the development of seismology as a science. In 1923, the American physical chemist, Leason Heberling Adams (1887-1969) and Scottish mathematical physicist, Erskine Douglas Williamson (1886-1923), both working at the Geophysical laboratory of the Carnegie Institution, Washington, published the first density-depth curve for the Earth, establishing beyond doubt the presence of an iron or iron-nickel core having a diameter of about half that of the Earth.

\section{CORRECTING GRAVITY OBSERVATIONS}

As experience grew, field measurements of the intensity of gravity (or, in the early work, the lengths of the pendulum) became subject to standard corrections. The first of these came to be known as the Bouguer reduction, after Bouger's (1749) work. This accounts for the attraction of an infinite horizontal plate of average density and constant thickness interposed between sea level and the station:

$$
g_{0}=g[1+(2 h / R)(1-3 \delta / 4 \Delta)]
$$

where $g$ is the intensity of gravity measured at the observation station and $g_{0}$ at sea level; other symbols as above (p. 230). If a given station is higher than the reference level, the observed value of gravity is increased, because of the attraction of the slab of material between the two; if the station is lower, it is subtracted because of the lack of attraction from the missing slab of material.

In 1880, the French astronomer Hervé Auguste Etienne Faye (1814-1902) suggested that this formula overcorrected in many cases, particularly with observations made on volcanic islands (thus accounting for the anomalous results remarked on by Airy in 1845; see Part I of this review, Figure 9B). Omission of the second term gives:

$$
g_{0}=g(1+2 h / R)
$$

which came to be known (Putnam 1895b) as the reduction to sea level, or free-air reduction. Faye recommended that one should also include a correction for local deviations of the station from the general level of the land (or sea bottom), substituting for $h$ the difference between the average elevation and the station elevation, and using an estimate of local density (preferably obtained by collecting rock samples from the vicinity of each station).

This led to the idea of terrain reduction, as suggested by the German geodesist, Friedrich Robert Helmert (1843-1917) in 1884 and by George Rockwell Putnam (18651953) of the U.S. Coast and Geodetic Survey in 1894 (Putnam 1895a). The idea was similar to that used by Hutton and Playfair in their work on Schiehallion in 1801 (Figure 1): the area surrounding a station was divided up into a series of concentric circles of increasing radii ("zones"), each ring subdivided into a number of sectors ("compartments"), 
each defining a prism of rock; the topographic contributions from each zone are summed to obtain the final correction (Putnam 1895a). Beginning with Hayford and Bowie (1912, Illustration 10), a number of different computational schemes for achieving this were suggested (summarised by Broughton Edge and Laby 1931, pp. 309-317; Heiland 1940, pp. 228-239; Jakowsky 1940, pp. 217-222), mainly distinguished by different ways of subdividing the circular mesh of cells.

The difference between the final corrected gravity value for a station and the theoretical value predicted by the spheroid model used (see Part I), gave what came to be called the free-air anomaly or the Bouguer anomaly (Hayford and Bowie 1912, p.76), depending on which reduction was applied. The term "anomaly" seems to have been introduced in the early 1900s; it does not appear as a key word in Gore (1903), but was used by Haasemann (1905) and in the title of Bowie (1912a).

In the older literature, units were expressed "for clarity" (Bowie 1912b, p.6) in terms of attraction as "dynes" rather than acceleration "cm."; the worldwide mean gravity value $g$ being about 980 dynes $\mathrm{gm}^{-1}$ or $980 \mathrm{~cm} \mathrm{~s}^{-2}$ respectively. The term Gal (after Galileo) was originally introduced by the German physicist, Arthur Joachim von Oettingen (18361920) in a paper on units of speed and acceleration (von Oettingen 1897). Following von Oettingen's terminology, the geophysicist, Emil Wiechert (1861-1928) introduced both Gal. (p. 228) and milligal (p. 231), $10^{-5} \mathrm{~m} \mathrm{~s}^{-2}$ ( $\mathrm{g}$ is about $980000 \mathrm{mGal}$ ), into the geophysical literature in 1897. Despite its original usage, in pre-1980 literature, the latter was often written as mgal rather than mal.

As instrumentation with higher precision became available, it came to be realised that corrections for lunar tidal effects and instrumental drift were also desirable. The overall change was measured by re-occupying a reference station at the end of a day's surveying and measuring the apparent gravity value for a second time. By assuming a linear rate of change with time, any apparent change in the base-station result could be applied in a proportional manner to values obtained at other stations occupied during the day.

As the nineteenth century progressed, the expanding geodetic networks encountered regions of mountainous topography, particularly in northern India and in the Rocky Mountains of the United States. The results obtained revealed an additional factor which influenced the measured intensity of gravity in such areas, and which needed to be taken into account in correcting the results.

\section{THE HIMALAYAN EFFECT}

In 1805, measurement of the Great Meridional Arc of India, a traverse along the seventy-eighth meridian, from Punnae on the southern tip (lat. $8^{\circ} 9^{\prime} \mathrm{N}$ ) across the Deccan plateau to Damargida (lat. $18^{\circ} 3^{\prime} \mathrm{N}$ ), began under Lieutenant-Colonel William Lambton (1756-1823) and Lieutenant George Everest (1790-1866). It constituted a key segment of the Great Trigonometrical Survey of India (Keay 2000). Following Lambton's death, Everest, now Surveyor-General, extended the arc northwards to Kaliana (lat. $29^{\circ} 30^{\prime} \mathrm{N}$ ), and reached it in 1834. This gave a total length of $1477 \mathrm{mi}(2377 \mathrm{~km})$, one of the longest arcs ever measured. Over six years, the pendulum was swung at thirty-one stations and the usual comparison was made between astronomically-based latitude determinations and the results of direct ground measurement. Everest found a difference in latitude of 5.24 " of arc over the $375 \mathrm{mi}(603 \mathrm{~km})$ distance between Kalianpur and Kaliana, the triangulation-based measurement being the larger. Since the maximum error attributable 
to the triangulation network, which had been measured with immense care, was only $0.006 "$, it was evident that the cause of the discrepancy must lie elsewhere.

This problem was taken up in 1854 by the Venerable John Henry Pratt (1809-1871), Archdeacon of Calcutta, an English mathematician and minister of religion, who had gone out to India as a chaplain to the East India Company in 1838. Pratt had a strong interest in the Figure of the Earth and had already published a book on the subject in 1836. He realised that the effect described by Everest could be consistent with an attraction caused by the mountain mass of the Himalayas, which lay north of Kaliana. However, when he calculated the expected attractive effects (based on topographic data from Everest's survey and with the assumption of a uniform density of $2.75 \mathrm{gm} \mathrm{cm}^{-3}$ ), he found that the deflections at Kaliana and Kalianpur should have been 27.85" and 11.97" respectively. These values yielded a theoretical difference of $11.88^{\prime \prime}$ which, to his surprise, was considerably greater than the observed value of 5.24". He communicated his finding to the Royal Society in December 1854 (Pratt 1855).

A little under two months later Airy, prompted by Pratt's contribution, also sent the Society a short manuscript, in which he stated that such a result should have been anticipated and that

instead of expecting a positive effect of attraction of a large mountain mass upon a station at a considerable distance from it, we ought to be prepared to expect no effect whatsoever, or in some cases even a small negative effect (Airy, 1855, p. 101).

Airy based this on a conceptual model in which the rocks of the outer crust rested on top of an inner sphere containing a fluid ("lava") of greater density. He suggested that rocks which formed an elevated table-land (such as was believed by Pratt to lie north of the Himalayas) could only do so because:

\begin{abstract}
there can be no other support than that arising from the downward projection of a portion of the Earth's light crust into the dense lava; the horizontal extent of that projection corresponding rudely with the horizontal extent of the table-land, and the depth of its projection downwards being such that the increased power of flotation thus gained is roughly equal to the increase of weight above from the prominence of the table-land. ... [T] he state of the Earth's crust lying upon the lava may be compared with ... a raft of timber upon the water; in which, if we remark one log whose upper surface floats much higher than the upper surfaces of the others, we are certain that its lower surface lies deeper in the water than the lower surfaces of the others (Airy, 1855, p. 103).
\end{abstract}

Airy argued that the positive gravitational attraction of the elevated portion would be counterbalanced by the effect of the less-dense material at depth. The net result would therefore be an attraction less than that which would be expected from the topographic effect alone. However,

it does not apply in regard to such computations as that of the attraction of Schehallien and the like. It applies only to the computation of the attractions of high tracts of very great horizontal extent, such as those to the north of India (Airy 1855, p. 104).

Four years later, Pratt (1859) took up a completely contrary view to Airy's, when he suggested that mountain chains had been forced up by a process of "thermal attenuation", and could therefore only exist by virtue of being made of material of lower density than the adjacent crust. Whereas Airy's model had blocks of similar density descending to different depths in the mantle as their elevation above sea level increased, Pratt's blocks rested on a constant-depth mantle and decreased in density with increase in elevation 


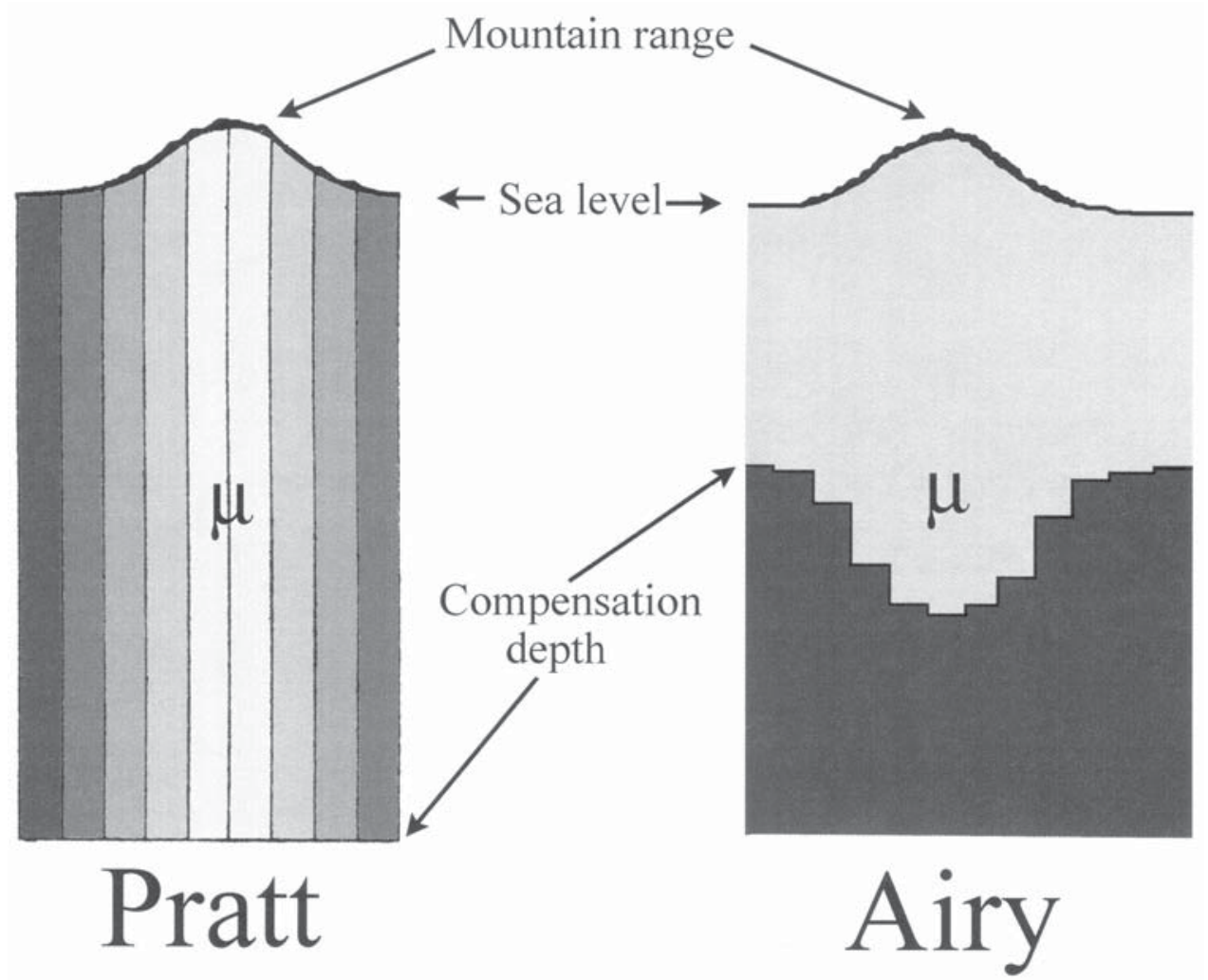

Figure 2. Comparison of the Pratt and Airy models for isostatic compensation. $\mu$ marks the approximate centre of gravity of the compensating mass. Increasing tone of shading represents increasing lithological density. (Redrawn from Evans and Crompton 1946, Fig. 1).

(Figure 2). Both were consistent with a constant-pressure crust-mantle interface and accounted for the observed gravity field surprisingly well. Pratt's model was founded on his ideas of the origin of mountains by unequal vertical expansion of the crust. Compensation was spread through about $100 \mathrm{~km}$ of crust, whereas in the Airy model the compensation depth was more like $50 \mathrm{~km}$. Considerable contemporary debate ensued as to which model was to be preferred, and regarding their implications for the thickness of the crust; see Kushner (1990, Chapter 2) and Watts (2001), for discussion.

\section{AMERICAN DEVELOPMENTS}

By the 1880s, the difficulties of carrying out pendulum operations in the field had prompted the design of more portable apparatus by von Sterneck in Austria (see Part I) and by Colonel Étienne Gilbert Defforges (1852-1915) in France. In 1893, Defforges brought his equipment to America to swing at some of the base stations of the Coast and Geodetic Survey (CGS) and measured the absolute force of gravity at Washington (Putnam 1895a,b; Mendenhall 1895). Taken together with a few observations already obtained by the CGS, it suggested that an unexpected variation in the force of gravity might be occurring in the interior. In 1891, the physicist, Thomas Corwin Mendenhall (1841-1924) developed a more portable half-second pendulum apparatus (Putnam 


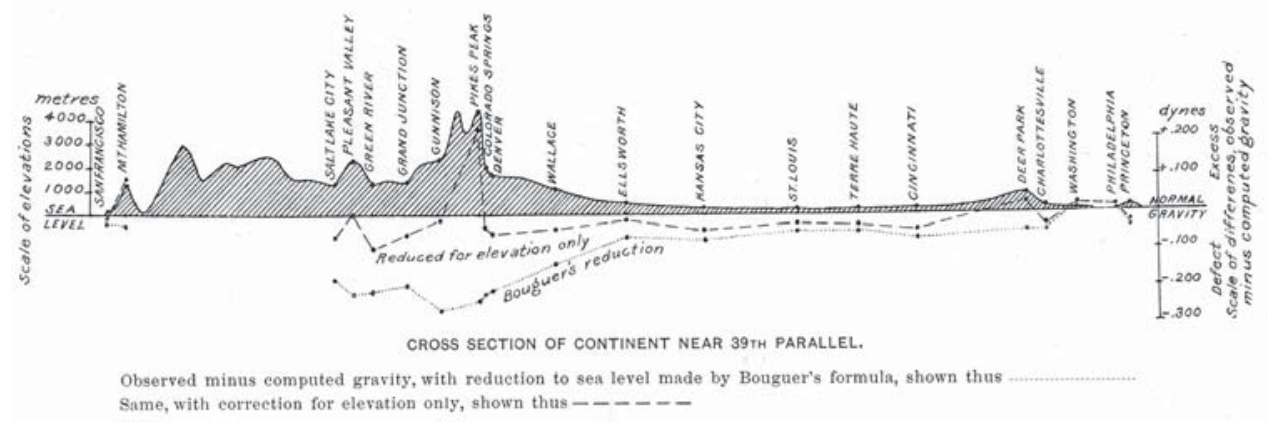

Figure 3. Free-air and Bouguer anomalies approximately along the line of the 39th parallel across the United States. Calculated with reference to Clarke's (1866) spheroid; range of residuals is -0.3 to 0.2 dynes (-300 to 200 mGal) (Putnam 1895a, Fig. 4, Plate 1).

$1895 \mathrm{a}, \mathrm{b})$ and in the Summer of 1894, this was swung at twenty-six stations lying broadly along the thirty-ninth parallel, on a line from Washington to San Francisco, crossing the Rocky Mountains near Pike's Peak (4293 m) in Colorado.

Analysis of the results by Mendenhall (1895), using residuals from Clarke's (1866, pp. 280-287) spheroid revealed a negative Bouguer anomaly whose magnitude increased inversely with the altitude of mountain ranges. Like Pratt in India, he concluded that it must be related to a lower density of the rocks beneath the elevated regions. His conclusions were supported by Putnam (Figure 3) but, because the magnitude of the Bouguer anomaly increased with the average elevation surrounding each station, Putnam suggested that the use of Faye's reduction might be preferable, as it greatly reduced the magnitude of the negative anomaly under the mountainous region (Putnam 1895b, pp. 52-53).

\section{ISOSTATIC COMPENSATION}

The American geologist Clarence Edward Dutton (1841-1912) coined the term isostasy (from the Greek isostatikos, meaning equal pressure) in 1889, to refer to the equilibrium surface taken up by a rotating inhomogeneous Earth which bulged where it was lighter and was depressed where it was more dense. Although his definition was couched in the language of Pratt's model, the word was subsequently applied to the mechanism which enables hydrostatic equilibrium to be maintained at the "depth of compensation." This means that the same pressure is exerted per unit area at the base of each hypothetical column of crust, "floating" on the denser material of the underlying mantle, regardless of whether it underlies ocean, lowland, or mountain chain.

Prior to 1903, only a total of 29 pendulum stations had been occupied in India, compared with 47 in Great Britain, 89 in France, 108 in the United States, 153 in Russia, 193 in Italy, 208 in Germany and 569 in Austria (Burrard 1905, p. 16). The increasing spatial density of data becoming available, particularly in Europe, made it possible to produce isoline (isogam) maps of the regional gravity field. Typical of this early work is Figure 4, based on 66 stations in the Harz mountain region of northern Germany, published in 1905 by the German geodesist Ludwig Haaseman (1857-1941), a Professor in the Geodetic Institute of Potsdam.

In 1889, the American civil engineer, John Fillmore Hayford (1868-1925), was 

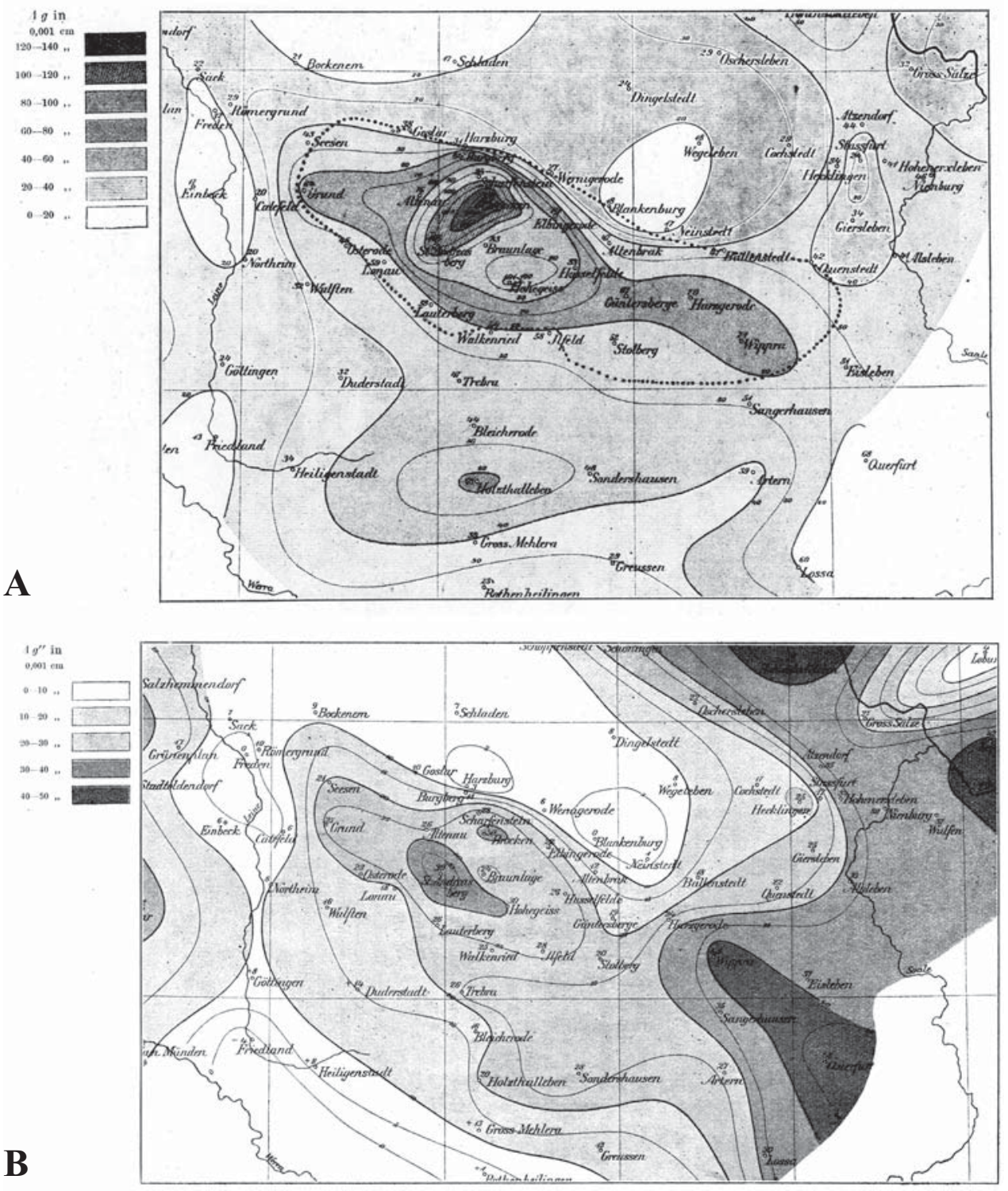

Figure 4. (A) Total gravity map and (B) Bouguer anomaly map of the Harz mountain region, Germany. Range of isogams is 0 to $50 \mathrm{mGal}$ (Haasemann 1905; reproduced from Fig. 5 in Born 1923).

appointed "computer" (i.e. a person who undertakes sets of routine, although complex, calculations) to the U.S. Coast and Geodetic Survey. By 1900 he had become an expert geodesist in charge of their "computing" division and, by 1910, he had become firmly convinced that " $[\mathrm{t}]$ he geodetic observations show that isostatic compensation [with a most probable compensation depth of $76 \mathrm{mi}(122 \mathrm{~km})$ and limits of 62-87 $\mathrm{mi}(100-142$ $\mathrm{km})$ ] is nearly complete" (Hayford 1911, p. 200) and that "[i]t is certain that a readjustment toward isostasy has been in progress during the period covered by geologic 


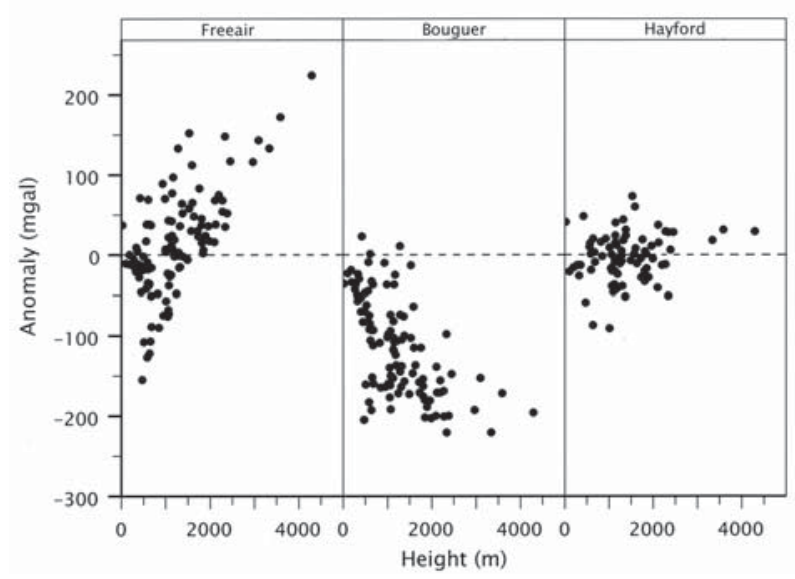

Figure 5. Comparison of magnitude of Free air, Bouguer and Hayford (113.7 $\mathrm{km}$ compensation depth) gravity anomalies ( $m G a l)$ as a function of height $(\mathrm{m})$ for 110 mountains in the United States, Canada, India and East Africa (data from Heiskanen and Vening Meinesz 1958, Tables 7-1 to 74).

record" (p. 201). In 1912 he jointly published with his colleague, William Bowie (18721940), a method for correction of gravity based on a Pratt isostatic model which used a compensation depth of $113.7 \mathrm{~km}$.

The amount of isostatic reduction was calculated in a similar way to a terrain correction: The area within $180^{\circ}$ of the observation point was divided up into a series of concentric zones (Hayford and Bowie 1912, Illustration 10). In each zone the density of the column between the surface and the depth of compensation was assigned in such a way that the total weight of each column of rock was the same, so that density was inversely proportion to the average topographic height. The attractions at the station due to the mass excess or deficiency in each zone were then summed to give the final correction. The compensation depth was generally chosen so as to give the smallest average anomaly. The correction applied to the observed value of gravity ( $g$, dynes) at the station was: $g+\left\{2 g_{0} / R[h+3(h-h) \delta / 4 \Delta]+T\right\}$, where $g_{0}$ is the theoretical value of gravity at the station at sea level; $h$ is the elevation of the station above sea level $(\mathrm{m}) ; h$ is the average elevation of the region about the station $(\mathrm{m}) ; R$ is the radius of the earth $(\mathrm{m}) ; \delta$ is the specific gravity of matter lying above sea level; $\Delta$ is the mean specific gravity of the Earth; and $T$ is the topographic correction, the effect of the departure of the surface about the station from a level plain.

The free-air, Bouguer, and "new method" or "H-method" (Hayford) gravity anomalies were all calculated with respect to a slightly modified version of the Helmert (1901) formula for the spheroid: $g_{0}=978.030\left(1+0.005302 \sin ^{2} \theta-0.000007 \sin ^{2} 2 \theta\right)$, where $\theta$ is the latitude (degrees). $g_{0}$ was changed from its original value of 978.046 to 978.030 so as to refer to the value at Potsdam, Germany, rather than Vienna, Austria (letter from Helmert to Bowie, October 31, 1911; quoted in Hayford and Bowie 1912, p. 12).

The new method of reduction appeared to better account for the effect of the land mass surrounding the station and, unlike either the free-air or Bouguer reductions, produced anomalies which were uncorrelated with the altitude of the station (Figure 5), a point made by Hayford and Bowie (1912), Bowie (1912) and reemphasised by Burrard (1920).

In Hayford and Bowie's (1912, Illustration 16) map of the United States, the Rocky Mountains region, which coincided with a large negative Bouguer anomaly (Hayford and Bowie 1912, Illustration 17), now became part of a much larger area characterised by low- 

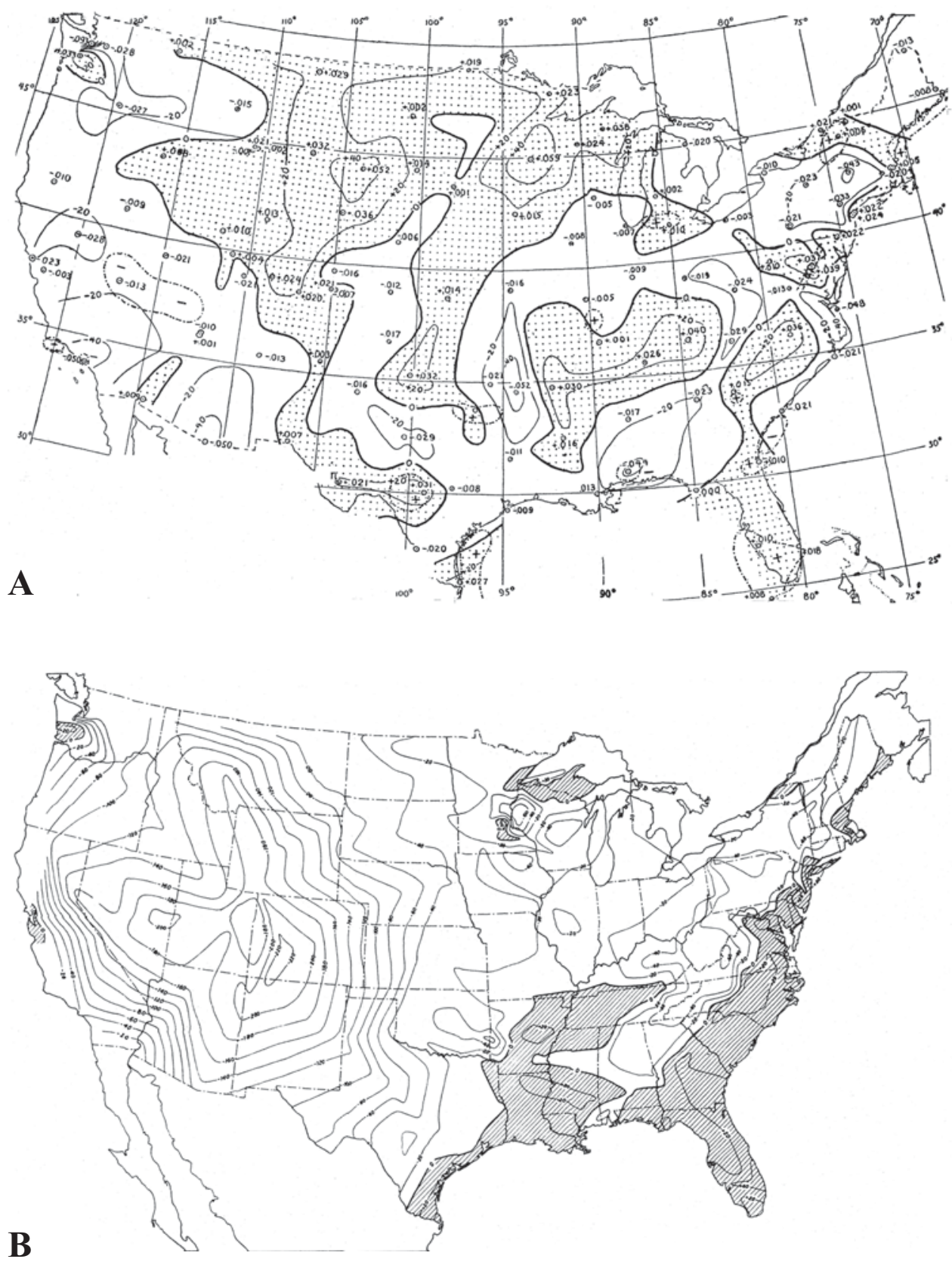

Figure 6. (A) Hayford anomaly map of the conterminous United States, based on 124 stations. Areas of positive residual are stippled. Range of isogams is -0.040 to +0.040 dynes $(-40$ to $+40 \mathrm{mGal})$. (Bowie 1912b, Fig. 2; reproduced from monochrome version in Barrell 1914, Fig. 5). (B) Bouguer anomaly map of the conterminous United States, based on approximately 200 stations. Areas of positive residual are shaded. Range of isogams is -0.220 to +0.040 dynes $(-220$ to $+40 \mathrm{mGal})$. (Bowie 1917, Fig. 13; reproduced from monochrome version in Heiland 1940, Fig. 7-40). 
magnitude positive anomalies. These came to be known as Hayford anomalies. Their study was subsequently updated as more data became available (Bowie 1912b, 1917; Figure 6) and attempts were made to interpret them in terms of the known distribution of major geological units. Negative Hayford anomalies tended to be associated with

the Cenozoic geologic formation .... located on or very near the coast .... probably explained by the presence of the very light material of all the Cenozoic formations which is present along nearly all the Atlantic and Gulf coasts of the United States .... in large part due to the presence of subnormal densities in the upper part of the crust below sea level. (Bowie 1917, p. 133).

Analysis of the available data (Bowie 1917, p. 81) showed the same occurred in India.

In 1931, the Finnish geodesist Weikko Aleksanteri Heiskanen(1895-1971) suggested a new compensation scheme based on Airy's isostatic model, which assumed that isostatic compensation is complete, that the compensating layers directly underlie the corresponding topography, and that the density of the mantle is $3.27 \mathrm{gm} \mathrm{cm}^{-3}$ (as compared to $2.67 \mathrm{gm} \mathrm{cm}^{-3}$ for the crust). Gravity anomalies for Pike's Peak in the United States, computed with the various models, were: Bouguer, $-196 \mathrm{mGal}$; Pratt-Hayford (using a $113.7 \mathrm{~km}$ compensation depth) $+29 \mathrm{mGal}$; and Airy-Heiskanen $(40 \mathrm{~km}$ compensation depth) $+19 \mathrm{mGal}$, respectively. Hence, despite the great difference between the basis of the Pratt-Hayford and Airy-Heiskanen models, they yielded similar amplitude anomalies in North America. This was taken as confirmatory evidence that the continent was, as Hayford had suggested, in a state of isostatic equilibrium (Heiskanen \& Vening Meinesz 1958, pp. 166-168, p. 188; Fig. 73, p. 196). Heiskanen's (1931) tables for the new scheme were revised by Vening Meinesz in 1941. Although some of the anomalies were reduced in magnitude by the Airy-Heiskanen reduction, in reality they remained strongly correlated with results obtained by Hayford's method (Figure 7)

After 1912, the interpretations of the Survey of India followed Hayford's method, again using the reference spheroid of Helmert (1901). Many of their reports included both regional Bouguer and Hayford anomaly maps, based on over 200 stations, in which the magnitude of the residuals was shown using either proportional-length symbols (Crosthwait 1912, unnumbered plate) or isolines (Couchman 1915, Chart IV; Glennie 1932, Charts II and III).

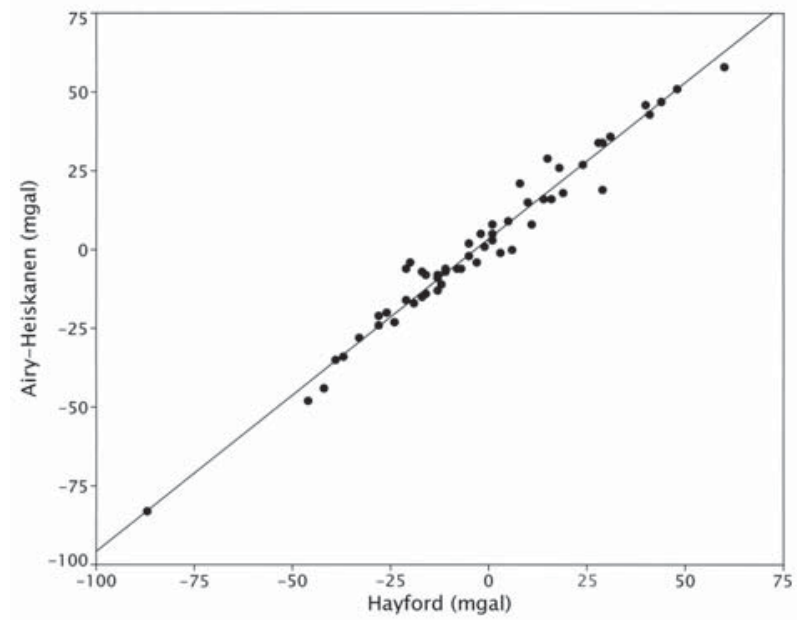

Figure 7. Comparison of magnitudes of Hayford $(H ; 113.7 \mathrm{~km}$ compensation depth) and Airy-Heiskanen (AH; 40 $\mathrm{km}$ compensation depth) gravity anomalies for 78 mountains in the United States, Canada and East Africa (data from Heiskanen and Vening Meinesz 1958, Tables 7-1, 7-2 and 74). Robust linear fit is $A H=3.418+$ $0.991 \mathrm{H} \mathrm{mGal}$. 
All the isostatically-compensated Hayford anomaly maps of the Indian sub-continent showed a number of features in common: A belt of generally positive anomalies running along the Lesser Himalayas; and a negative belt in the foot-hills, running from Dibrugarh to Peshawar, in part attributable to the low-density alluvial material underlying the IndoGangetic plain. This was followed by a generally positive belt, crossing Peninsular India between the 21st and 26th Parallels; and finally, a belt of negative anomalies south of the 21st Parallel. The amplitude of the negative anomalies steadily increased towards the southern tip of India and into Ceylon (now Sri Lanka). However, the use of isostatic compensation models as an interpretation tool certainly required caution, not least because the compensation depth used grew shallower as more data accumulated: 114.5 km, 1906; 113.0 km, April 1909; 122.2 km, December 1909; 113.7 km, 1912; 96 km and $60 \mathrm{~km}, 1921$ (Washington 1922, p. 408).

The negative pattern in the Hayford anomaly maps over the dense Precambrian rocks of southern India proved particularly hard to explain, as Hayford and Bowie's work had shown positive isostatic anomalies over similar rocks in the United States. In contrast to this, the Indian Bouguer anomaly map showed a more simple pattern: Generally positive anomalies in coastal areas changed to low negative values over the major portion of the land mass (becoming somewhat more negative between the 20th Parallel and the southern tip of India) decreasing northwards, to become major negative anomalies over the Lesser Himalayas and their foot-hills.

It was not until 1956 that the negative Hayford anomaly in the south was shown to be an artefact: the result of an inappropriate choice of model for the spheroid, combined with the use of a single depth of compensation for both the Himalayas and the Peninsula. Had either the Pratt-Hayford or Airy-Heiskanen models been applied using different compensation or crustal depths for the Himalayan and Peninsula regions, much more reasonable results would have been obtained. The average anomaly over the Precambrian terrain of southern India was shown by the new study (Gulatee, 1956) to be slightly positive, thus falling into line with the results obtained in the United States.

Independent evidence for the concept of isostasy was obtained from repeated topographic surveys in Fennoscandia, carried out between 1892 and 1953. Differences in topographic elevation revealed an ongoing uplift of the land mass at about $1 \mathrm{~cm}$ per year, interpreted as isostatic adjustment. The land-mass gradually floating upward as a result of the loss of the weight of an ice-cap (perhaps 2000 to $2500 \mathrm{~m}$ thick) which covered the region at the time of the last Ice Age, some 18,000 years ago (Born 1923, Chapter 8; Heiskanen \& Vening Meinesz 1958, pp. 212-215).

An entirely different line of evidence was provided in 1922 by the American petrologist, Henry Stevens Washington (1867-1934), who calculated the mineralogical composition of forty-seven suites of igneous rocks collected from different regions of the globe from their chemical compositions. He calculated the equivalent percentages of the same suite of normative minerals (quartz, orthoclase, albite, anorthite, leucite, nepheline, corundum, wollastonite, enstatite, ferrosilite, forsterite, fayalite, magnetite, ilmenite and apatite); then, since the densities of each mineral type were known, the overall normative density of each rock type was obtained (Washington 1922, pp. 386-387). Comparing these to average altitudes for each region, he confirmed that density appeared to be inversely correlated with topographic elevation.

Nevertheless, with the passage of time, geologists became increasingly uncomfortable with the Pratt model. Evans and Crompton (1943, p. 215) concluded that, despite its widespread use in the Hayford method of gravity reduction, it "cannot be regarded as 
having any real basis."

It is now known that both the Pratt and Airy models were based on unrealistic assumptions: (i) that the elevated regions consist of blocks bounded by vertical faults, which enable them to move up or down independently; and (ii) the mantle behaves like a fluid. Most recent orogenic belts tend to have deep crustal roots (Airy), but some areas of marked elevation have hotter, and therefore lower-density, mantle rocks than is usually the case (Pratt), but the more simplistic aspects of their models are no longer accepted. See Watts (2001) for discussion.

\section{UNDERWATER}

One of the more exotic applications of the pendulum to regional gravity surveys was by the Dutch geophysicist, Felix Andries Vening Meinesz(1887-1966). After graduating as a civil engineer in 1910, he worked for the Commission on Arc Measurement and Levelling in the Netherlands. In the early 1920s, there arose an international requirement to attempt a better definition of the shape of the geoid (see Part I) from gravity data. This led him to think of using a submarine to make gravity measurements in oceanic areas.

Following the earlier success of the two-pendulum apparatus he had adopted for surveys over the unstable peaty soils of the Netherlands, he developed a gimbal-mounted three-pendulum instrument for submarine use (Part I, Figure 6B). When the submarine was immersed at a depth of 20 to $40 \mathrm{~m}$, so that its rolling and pitching were minimised, the new instrument was capable of making gravity measurements with a precision of a few mGal.

During a series of voyages made in 1923, 1926-27, 1929-30 and 1934-35, Vening Meinesz circumnavigated the World and made measurements at about 1,000 sub-sea stations (Veldkamp 1984, pp. 83-89; complete bibliography in Bruins and Scholte 1967). His results showed that use of the traditional bi-axial ellipsoid, rather than a tri-axial ellipsoid, yielded the best approximation to the geoid. Of more interest to geologists, however, was his discovery and mapping (Vening Meinesz 1934; Heiskanen \& Vening

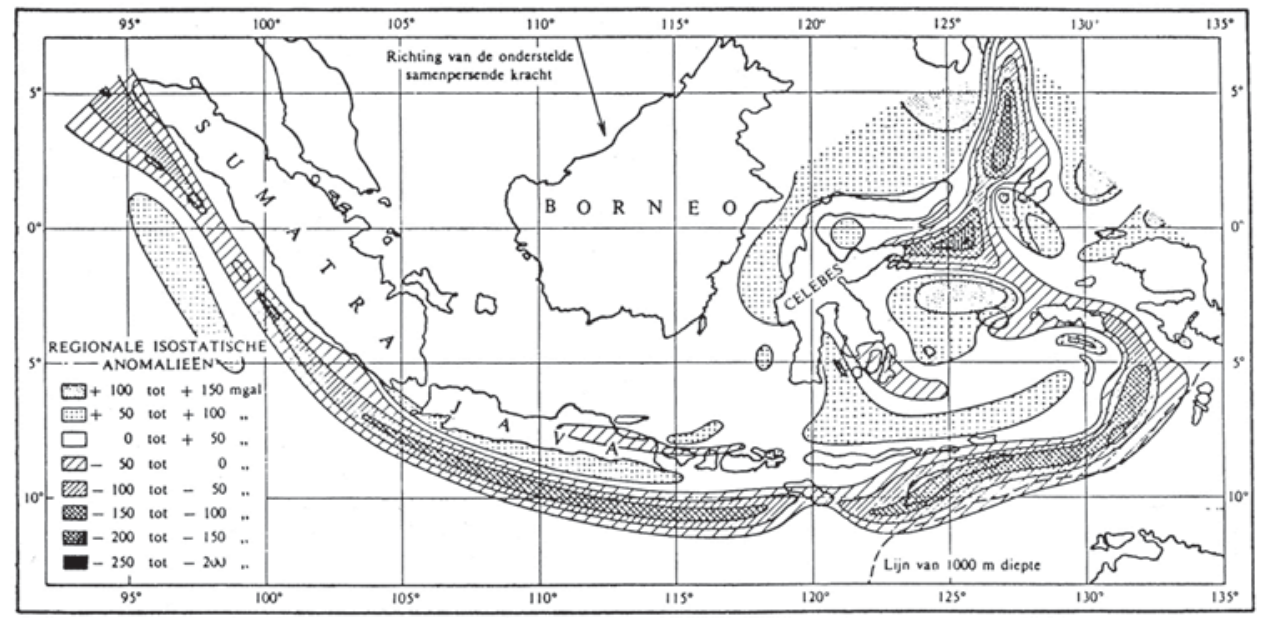

Figure 8. Vening Meinesz's map showing a large negative Airy isostatic gravity anomaly associated with the deep sea trench off the Indonesian Archipelago. Range of isogams is -250 to + $100 \mathrm{mGal}$. (Vening Meinesz 1934). 
Meinesz 1958) of a belt of strongly negative Airy isostatic-anomalies associated with the deep oceanic trenches off the East Indian Archipelago (Figure 8) which he interpreted as indicating the presence of a low density "root" beneath the trench. (Modern seismic work has shown the trenches to be associated with subduction of the oceanic crust beneath the island arc lying to the north).

The geological results from determinations of gravity described so far been at a regional, or even continental, scale. All were obtained through the use of pendulum measurements but, with a few notable exceptions (such as the instrument developed by Vening Meinesz) the apparatus remained relatively insensitive, difficult to transport, and unsuited to making the detailed measurements required for geophysical exploration. Shaw (1917) had expressed a hope that pendulum surveys might be utilised in the search for salt domes, but this was not in fact realised until 1929 (see below).

The introduction of a series of new instruments, designed on quite different principles from the 1880 s onwards, provided increased measurement sensitivity and greatly increased portability. This new instrumentation enabled the focus to shift to much more detailed observations and for the first time, provided tools to aid in the exploration for deposits of economic significance.

\section{FROM TORSION BALANCE TO GRAVIMETER}

Interest in obtaining a more accurate determination of the mean density of the Earth prompted the use of the torsion balance by Cavendish (1798), based on a principle first discovered by the French physicist, Charles Augustin de Coulomb (1736-1806), who had constructed one in 1785 to make electrical measurements (Coulomb 1788). Subsequently, the English geomagnetist and meteorologist, John Allan Broun (1817-1879) and the French physicst, Jacques Babinet (1794-1872) described devices for the measurement of gravity on the same principle (Broun 1863, Babinet 1863), but subsequent investigation by J. Herschel $(1880,1881)$ suggested that their efforts had not produced workable instruments. Another, similarly unproven, proposal (Anonymous 1862) for a torsion balance came from another Frenchman, M. Perrot (possibly the physicist, Adolphe Perrot, ?fl. 1833-1887).

The breakthrough came some twenty years later, with the work of the Hungarian physicist, Baron Loránd ("Roland") Eötvös (1848-1919). He came of a distinguished line of Hungarian nobility and entered the University of Budapest to study law in 1865 but he took additional classes in science and mathematics. By 1867, he had given up law, and moved to the University of Heidelberg, where he studied mathematics, physics and chemistry, obtaining his doctorate in physics in 1870 . The following year he returned home to become a physics lecturer at Pest (later Budapest) University, where he remained for the rest of his career. He was appointed Professor of Theoretical Physics in 1872 and of Experimental Physics in 1878. Apart from seven months of service in the Cabinet office in 1894, as minister of religion and public education, his work as a physicist continued until his death in 1919 (Vajk 1949; Ádám 2000).

Motivated by a desire to improve methods for the measurement of gravity, Eötvös began his work in 1886. He recognised that the presence of a difference of mass distribution in the crust would slightly change the direction and magnitude of the "vertical" force of gravity (Bouguer's "attraction of a mountain" on a far smaller scale) giving rise to curvature of the gravitational equipotential surface (Figure 9A) and realised that if the magnitude or direction of the horizontal component of gravitational force 


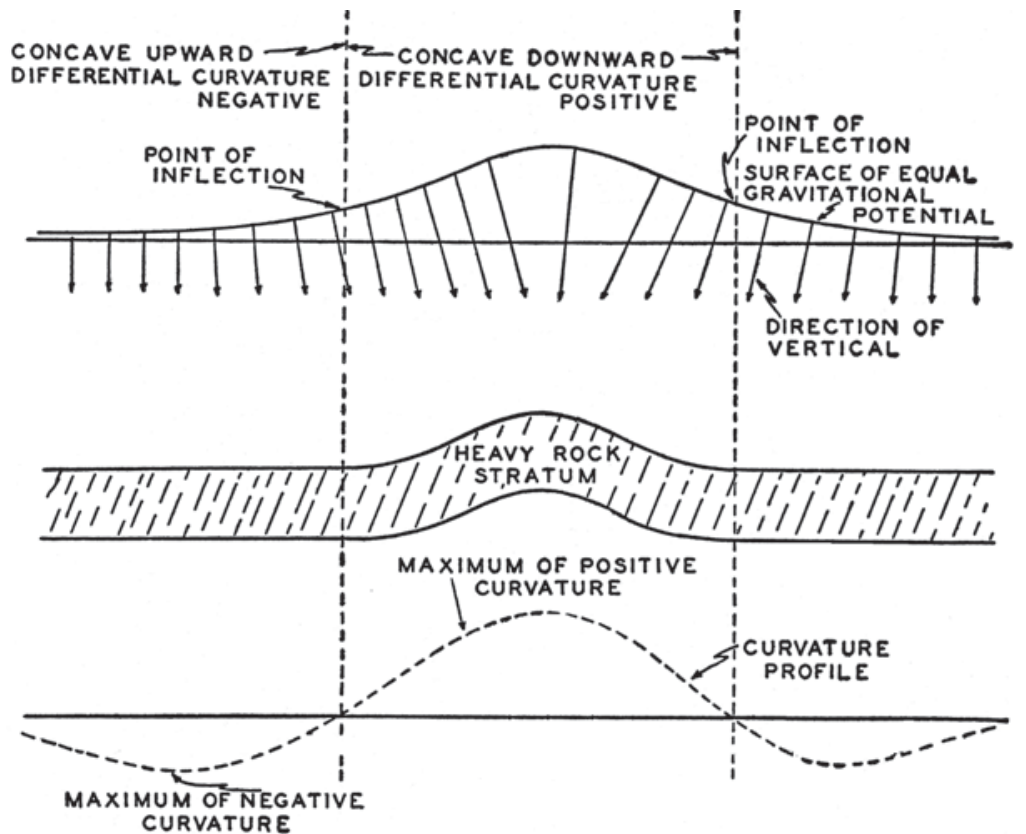

A

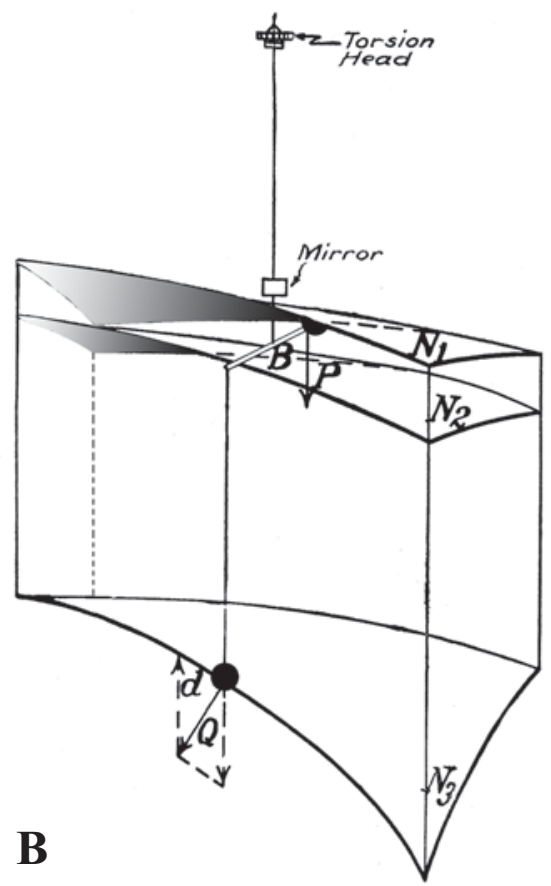

Figure 9. (A) Differential curvature of the niveau surfaces (equipotential surfaces everywhere perpendicular to the lines of force; Eötvös 1908) of the gravity field over an anticline (modified from Nettleton 1940, Fig. 48). (B) Spatial distribution of the forces on the Eötvös torsion balance beam: $N_{1}$ and $N_{2}$ are two niveau surfaces passing through the ends of the beam $B ; N_{3}$ cuts the centre of gravity of the lower mass; $P$ and $Q$ are the forces acting on the two masses; the resultant d leads to horizontal rotation as a result of torsion of the suspension wire (modified from Ambronn 1928, Fig. 5). 

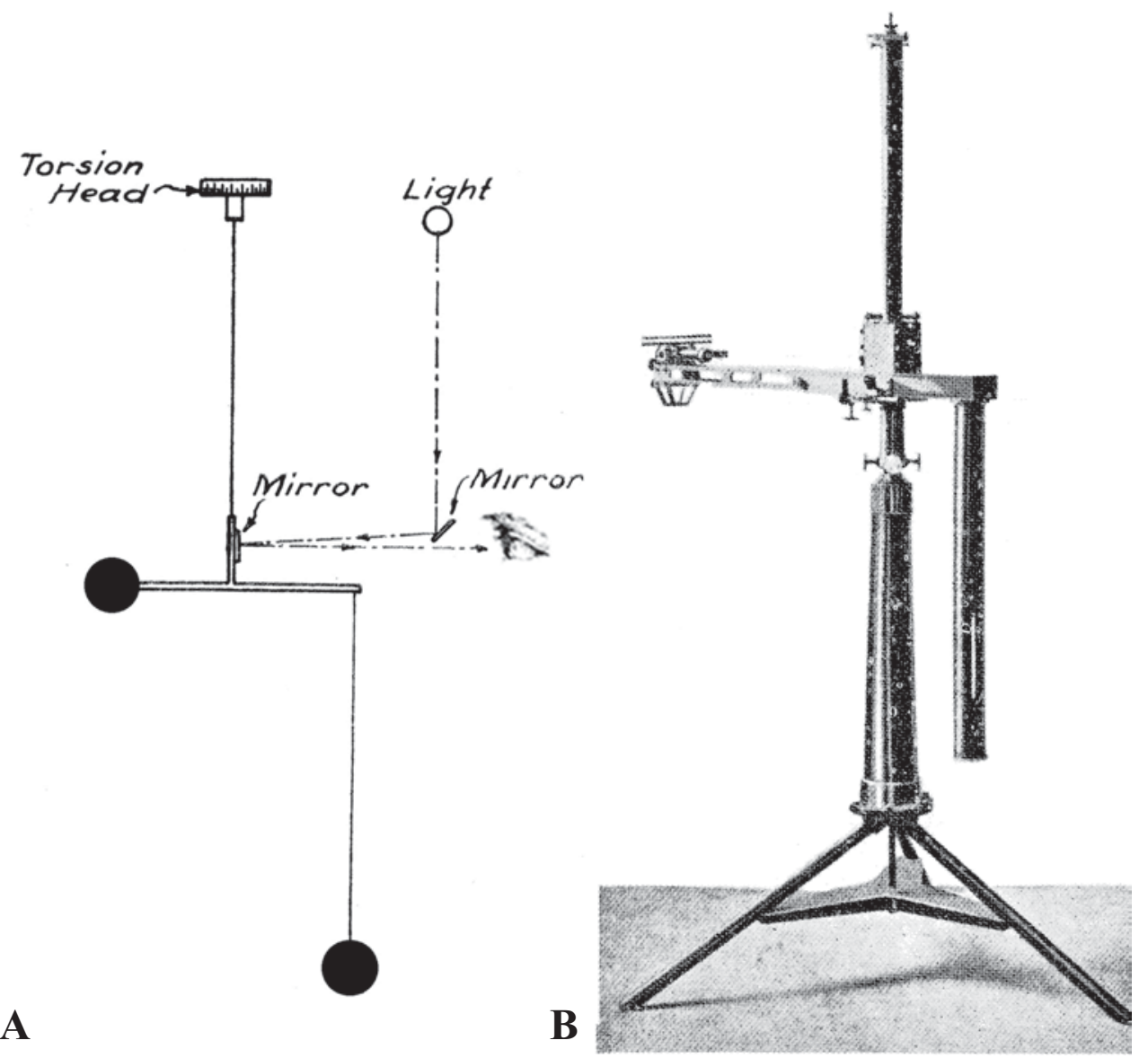

Figure 10. (A) Schematic of the Eötvös torsion balance (modified from Jakosky 1940, Fig. 101). (B) Eötvös' first (1898) torsion balance. (Pekár, 1928, Fig. 2).

differed at each end of a torsion balance beam, then the beam should experience a small torque, and move in the horizontal plane in response to this differential curvature (Figure 9B).

In 1889, he constructed a "horizontal gravity variometer," (Pekár 1928; Fig 1, p. 1080 ) in which a 12 gm platinum mass hung from a long $0.04 \mathrm{~mm}$ diameter platinum wire suspended from one end of a suspended horizontal beam, such that it was about $30 \mathrm{~cm}$ lower than the other counter-balancing mass, located at the opposite end of the beam. By using the principle of the mirror galvanometer (Thomson 1858), extremely small changes in torque, and hence the gravity field, could be detected (Figure 10). He made the first measurements at Gellért Hill in Budapest that year. His first real field trial was conducted in August 1891 at Sághegy, near Celldömölk in Transdanubia (Volgyesi 2001, p. 205) and the first paper describing his results was published in 1896.

In order to speed-up fieldwork, a double-sided instrument incorporating two balances was built in 1902 and modified versions, made either under his direction, or that of his former assistants, continued to be produced into the late 1920s (for details of the measurement techniques, see Eötvös 1896, Shaw and Lancaster-Jones 1927, Broughton 


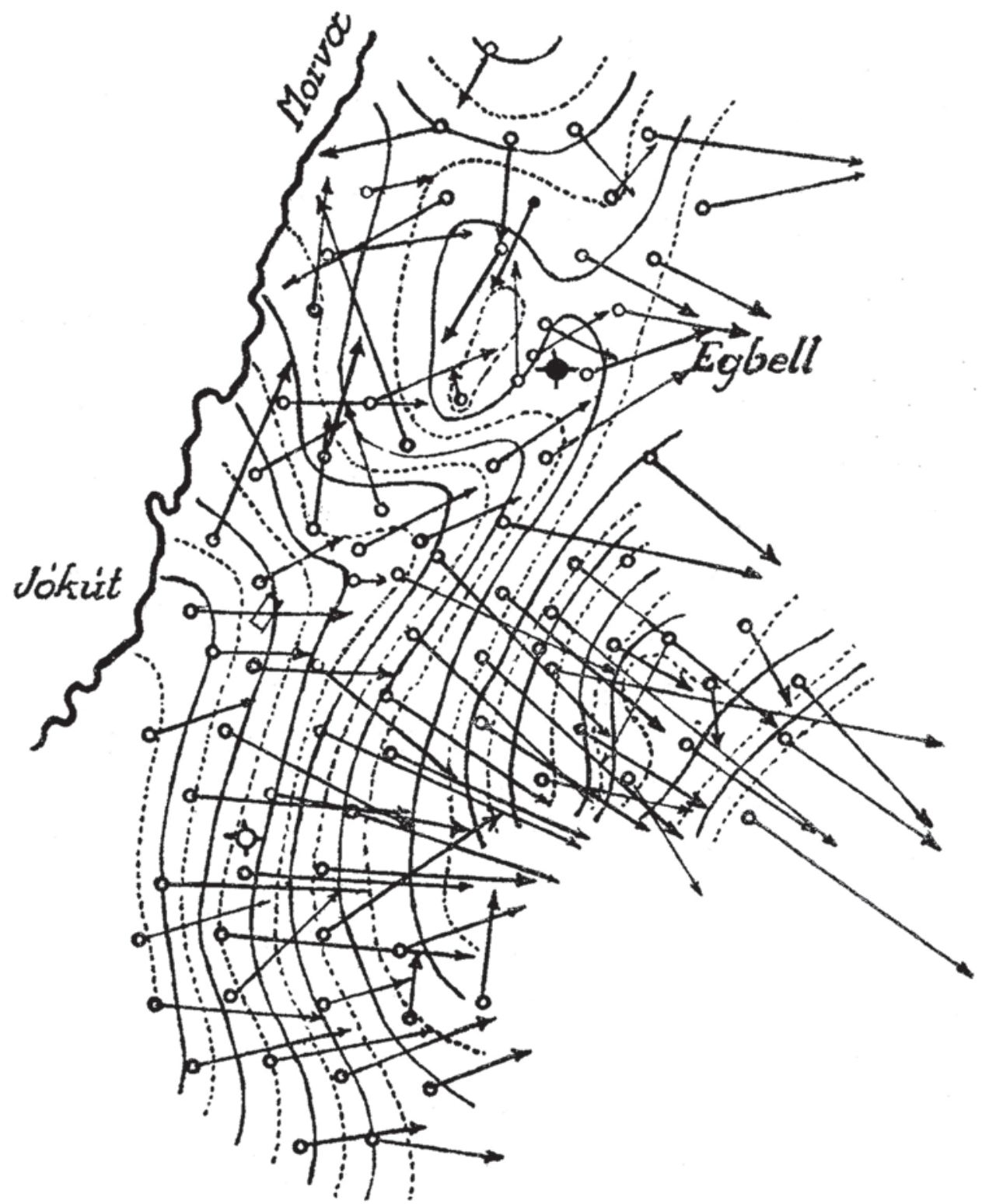

Figure 11. Torsion-balance map of the Egbell (Gbely) oil field (now in Slovakia) made by Eötvös' assistants Pekár and Fekete in 1915-16. Proportional-length arrows, showing magnitude of the horizontal gradient of gravity and direction of the maximum gradient, the contours (isogams) are in Eötvös units $\left(10^{-6} \mathrm{mGal} \mathrm{cm}^{-1}\right)$. Note symbol for well (to left of "Egbell") which struck oil in 1914, sited by de Böckh in 1913 on the crest of an anticline. (de Böckh,1934, Fig. 2).

Edge and Laby 1931, Weiss 1935 or Heiland 1940, pp. 170-292).

During the winters of 1901 and 1903, Eötvös and his assistants carried out experiments over the ice covering the $80 \mathrm{~km}$ long $\left(580 \mathrm{~km}^{2}\right.$ area) Lake Balaton, southwest of Budapest, measuring thirty-three stations in 1901, and a further twelve in 1903. Since its frozen surface was essentially perfectly level and its bathymetry was well established, it made an ideal environment to test how the instrument behaved in response 
to known changes in the sub-surface distribution of mass below the interface of the bedrock with the lake water.

Between 1902 and 1914, as a result of the current interest in isostasy, Eötvös carried out experiments in the Fruska Gora Mountains (parts of which now lie in Serbia, Montenegro and Croatia); the Arpuseni Mountains, near Arad, and in Transylvania (now in Romania), to try to outline the "root zone" of the mountains; and undertook a regional survey of the Debreczen area (Hungary), east of Budapest in 1917-21.

Eötvös' results were presented at a series of international conferences on geodesy in 1906, 1909 and 1912 (Eötvös 1908, 1910, 1913). They were illustrated using proportionallength arrows to indicate the magnitude and direction of the horizontal gradient vector and isolines to interpolate the magnitude and gradient between the data points (Figure 11). Denoting $U_{x z}$ as the rate of change of the vertical component of gravity in the direction of the $x$-axis, oriented towards the (magnetic) North and the $z$-axis vertically downwards; similarly, $U_{\mathrm{yz}}$ as the rate of change in the direction of the $y$-axis (East) and the $z$-axis; and in the horizontal plane $U_{\mathrm{d}}=U_{\mathrm{yy}}-U_{\mathrm{xx}}$, these effects could all be determined instrumentally. The gradient was shown by a line of length proportional to the vector mean of $U_{\mathrm{xz}}$ and $U_{\mathrm{yz}}$, i.e. $\sqrt{ }\left[\left(U_{\mathrm{xz}}\right)^{2}+\left(U_{\mathrm{yz}}\right)^{2}\right]$, drawn with its origin at the observing station. The curvature was shown by a line-segment of length proportional to $\sqrt{ }\left[\left(U_{\mathrm{d}}\right)^{2}+\left(U_{\mathrm{yz}}\right)^{2}\right]$, oriented along an azimuth $\theta$ where $\tan (2 \theta)=-2 U_{\mathrm{xy}} / U_{\mathrm{d}}$, the principal plane in which curvature was a minimum. The magnitudes of these vectors were expressed in Eötvös units (E): if the gradient is $1 \mathrm{E}$ then the intensity of gravity at two points $1 \mathrm{~cm}$ apart differs by $10^{-9}$ Gal cm $\mathrm{cm}^{-1}$ or, equivalently, $10^{-9} \mathrm{~s}^{-2}$. Values encountered in the field generally ranged from 5 to $50 \mathrm{E}$ and exceptionally up to about $150 \mathrm{E}$ (Barton 1929). These graphic symbols were subsequently adopted internationally as the standard for portrayal of the results of virtually all torsion balance surveys (Ambronn 1928; Weiss 1935; Heiland 1940; Jakosky 1940; Nettleton 1940; Stegena 1984), until they gradually fell out of use in the late 1930s (discussed below).

The English applied mathematician, Sir George Howard Darwin (1845-1912), who could himself be regarded as the founder of the British school of theoretical geophysics (Kushner 1990, 1993), and Helmert attended the 1906 meeting in Budapest at which Eötvös presented his results and demonstrated his method in the field in the Arad region. They were so impressed that they successfully petitioned the Hungarian government to give more funding for his gravitational studies, and this was done from 1907 onwards (Ádám 2000).

\section{The search for oil}

Salt deposits originate from large-scale evaporation of oceanic waters at former times in the Earth's history and are found in many parts of the world. Salt domes are typically mushroom-shaped structures, with "stalks" from 1.5 to $6 \mathrm{~km}$ across and up to $10 \mathrm{~km}$ in height, which have pierced through overlying rock strata as a result of plastic flow of the salt upwards from the thick source deposits, in response to gravity loading from the overlying sediments. Regions which contain salt domes mainly occur in parts of Germany, Romania, the Mediterranean, the Middle East, Russia and North America. Because injection of the salt can bow up the surrounding rock strata through which it passes, or which overlie the dome, by as much as $1 \mathrm{~km}$ over areas of up to $200 \mathrm{~km}^{2}$, salt domes create excellent sites for oil traps if there are source rocks nearby. By 1910, some domes had been found at the surface in Europe, Russia and the Gulf Coast of the United 
States, their presence indicated by seeps of oil, gas or brine and, on occasion, locallydomed rocks. However, a means to seek out buried domes was needed.

Up to this time, torsion balance surveys had simply been focused on determination of the depth to basement rocks beneath their blanket of overlying sediments. However, by 1912, Eötvös (1913) had realised that his regional isogam maps indicated the distribution of mass at depth, and suggested that a survey over the Great Hungarian Plain might be useful to locate anticlinal folds hidden under later cover. Hugo Böckh von Nagysur (de Böckh; 1874-1931), Professor of Geology in the Hungarian Royal High School of Mines suggested to Eötvös in 1915 that a gravity survey should be undertaken over the Egbell (Gbely) oil field ( $48^{\circ} 43^{\prime}$ N., $17^{\circ} 8^{\prime}$ E.), in the Carpathian mountains 55 $\mathrm{km}$ north of Bratislava (now in Slovakia), where de Böckh had located the first well in 1913 and which had struck oil in 1914 (de Böckh 1934; a posthumous account completed by the British geologist, Percy G.H. Boswell (1886-1960) from papers given to him by de Böckh's widow). The survey was carried out in 1915-16 by Eötvös' assistants Dezsõ Pekár (1873-1953) and Jenõ Fekete (1880-1943). They occupied ninety-two stations, and found a positive gravity anomaly coincident with the dome of the anticlinal field (Figure 11), thereby confirming the potential of the method as an exploration tool. This work was carried out for the D'Arcy Exploration Company (an affiliate of the AngloPersian Oil Company) through Böckh (Rybar 1923, p. 661; Alexanian 1932, p. 155; Eckhardt 1949, p. 23).

In 1917 and 1918, the torsion balance was again successfully used by Eötvös and his associates, including Wilhelm Karl Schweydar (1877-1959) and de Böckh, to locate salt and potash deposits in Germany and Romania, and in the early 1920s, its potential for locating coal and metallic orebodies was also investigated (Shaw and Lancaster-Jones 1925, pp. 86-90). The gravity survey of the Wathlingen-Hänigsen district, near Celle, Hannover, in Germany was the first ever made of a salt dome. It successfully indicated where the edges of the dome were located outside the small area where this had already been established as a result of wells sunk over a small oil pool (Schweydar 1918).

Between 1923 and 1929, when de Böckh became director of the Hungarian Geological Survey, he was also geological advisor to the Anglo-Persian Oil Company and encouraged their first experimentation with torsion balance surveys (Stegena 1984; Ferrier 1982, pp. 426-429). James Clark Templeton (1898-1950), who had studied at the Eötvös Geophysical Institute in Budapest, and Richard Davies began the first survey for Anglo-Persian over the Ahwaz anticline, Persia (Iraq) in 1923. The structure was proved in 1924 and, from October 1924 to 1927, Davies, John Hugh Jones (fl. 1893-1941) and W.R. MacDonald, extended the survey to cover many of the other major structures (Sweet 1978, pp. 255-6). Royal Dutch Shell undertook surveys in Egypt in 1921, and Borneo in 1922 and 1924 (Sweet 1978, pp. 25, 350, 353); and the Burmah Oil Company worked in India at Khairpur in 1923-24, and in Upper Assam in 1925 and 1927-28 (Pekár 1928, pp. 1087-1088).

Even with improved torsion balances (later models used photographic recording), surveying was a slow business. A typical instrument stood about $1.8 \mathrm{~m}$ high and weighed at least $60 \mathrm{~kg}$. Because of sensitivity to near-by differences in mass, the ground on which the instrument was placed had to be levelled to within two degrees of the horizontal, and all scrub, grass and trees removed to a radius of five metres around the site of the instrument, and sometimes much further out, nor should it be close to a hill or depression with more than five degress of slope (Barton 1938b, p. 368). Three or four readings were needed at each station. These had to be taken with the azimuth of the balance rotated by 
Figure 12. Torsion balance map of the Nash Dome, the first significant oil field associated with a salt dome to be discovered in the United States by means of a geophysical survey. Discovered by Barton in 1924. (Barton, 1929, Fig. 9).

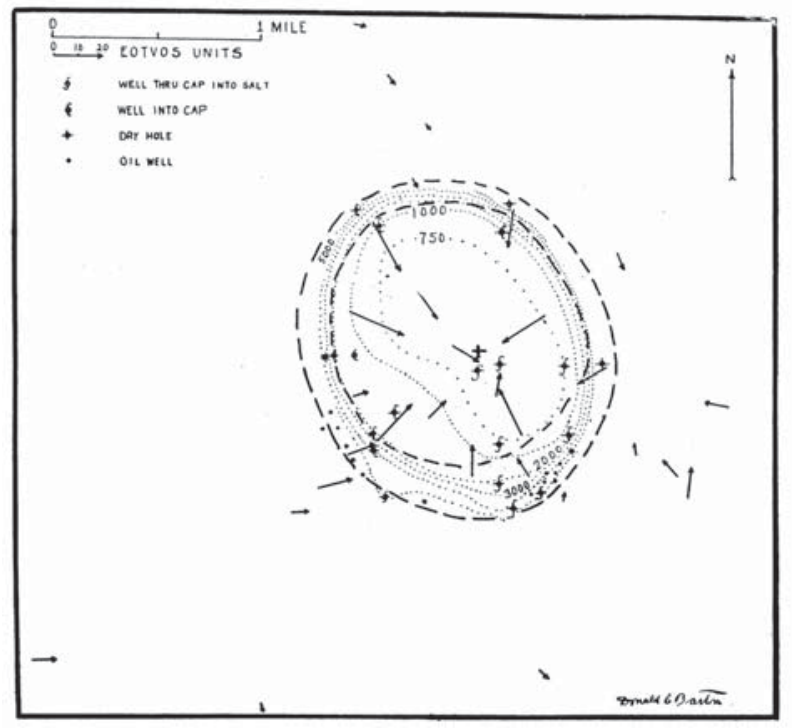

some $120^{\circ}$ each time, and the instrument needed to be left for some 40 to 50 minutes to attain equilibrium following each setting. With a two-man crew and locally-recruited labourers who levelled the sites beforehand, all working day and night, it was unusual to exceed 3 to 4 survey stations in 24 hours, and according to Barton in 1922 (quoted in Robertson 2000) a team of at least five persons was desirable.

The onset of World War I slowed transmission of this technology to the United States. The geologist and geophysicist, Everette Lee DeGolyer (1886-1956), Vicepresident and General Manager of Amerada Petroleum Corporation, had made two attempts to obtain a torsion balance from Eötvös in 1914 and 1918, but nothing came of this because of the difficulties imposed by the War. Shortly after it ended, DeGolyer travelled to England, where he visited "two members of the physics faculty of Cambridge University”, almost certainly Sir William Henry Bragg (1862-1942) and his son, William Lawrence Bragg (1890-1971) and, in London, the Swiss chief geologist of the Royal Dutch-Shell Group, Josef Theodor Erb (1874-1934). DeGolyer discussed with all of these persons "the feasability of locating salt domes in coastal Texas and Louisiana with the Eötvös torsion balance and with some form of seismograph" (DeGolyer in Sweet 1978, pp. 47, 119). Erb was already familiar with Eötvös" work and "was inclined to think it could be successfully used" (DeGolyer 1921, quoted in Robertson 2000).

Following Eötvös' death in April 1919, DeGolyer contacted Pekár in 1920 and arranged for two balances to be built in Budapest by Ferdinand (Nándor) Süss (18481921) of the Eötvös Instrument Company. In 1919, DeGolyer had hired the American petroleum geologist, Donald Clinton Barton (1889-1939) as a geologist with the Rycade Oil Corporation (a subsidiary of Amerada). Barton had taken an A.B., with geology as his major, at Harvard College in 1910, followed by an M.S. in 1912 and Ph.D. in 1914. He then spent two years as a teacher of engineering geology and a subsequent year as a field geologist, before serving in France with the American Expeditionary Forces during World War I. Under the influence of DeGolyer, he became increasingly interested in the application of geophysical methods and in 1922, he was sent by DeGolyer to Budapest to be trained by Pekár at the Eötvös Institute (Pratt 1939; Eckhardt 1949, pp. 23-24; 
Heiland, 1940, pp. 277-284; Barton in Robertson 2000).

Following Barton's return to the United States with the two torsion balances in September 1922, they were tested near Houston, following their journey. One was then sent to be used in Mexico by a subsidiary, the Mexican Eagle Oil Company, while the other was tried out by Barton over the Spindletop salt dome, near Beaumont in Jefferson County, Texas. The survey showed that the dome, which had been discovered in 1901 from surface gas seeps, was characterised by a positive gravity anomaly.

In the spring of 1924, a survey by Barton for Rycade used the same torsion balance to locate the previously unsuspected Long Point and Nash domes, south-west of Houston in Fort Bend County and Brazoria County, Texas. Long Point was thought to be barren (a small quantity of oil was discovered in 1950), but the Nash dome, thirteen kilometres to the south-east, was the first significant oil field associated with a salt dome to be discovered in the United States by means of a geophysical survey. The salt of the Nash dome comes to within $290 \mathrm{~m}$ of the surface and was again characterised by a positive gravity anomaly (Figure 12) from which Barton interpreted the structure, confirmed by drilling later that year. Rycade completed the first producing well in the field in 1926 (by 1965 it had produced $3.4 \mathrm{~m}$ bbl of oil) (Barton 1930a, Fig. 1; Halbouty 1967, pp. 55, 97 , 121, 178-179, 184-185).

Following his discovery of the Nash dome, Barton became chief of the Torsion Balance and Magnetometer division of the Geophysical Research Corporation (a subsidiary of Amerada). He left in 1927 to follow a distinguished career as a consulting geologist and geophysicist, first in private practice and, from 1935 until his death in 1939, with the Humble Oil and Refining Company (Pratt 1939). Vening Meinesz's sub-sea gravity observations in the Gulf of Mexico (see Part I) were used by Barton to complete the offshore portion of the first regional gravity map of the Texas Gulf Coast and northern Gulf of Mexico (Barton and others 1933, Fig. 2).

From 1923 onwards, the torsion balance and, to a much smaller extent, improved pendulum apparatus (Jakowsky 1940, pp. 162-168; Heiskanen \& Vening Meinesz 1958, pp. 98-101), became widely used in exploration for oil, particularly on the Gulf Coast of the United States, but also in Mexico, Venezuela and West Africa (Sweet 1978, pp. 153, $205,217)$. Improvements were made to the instrument with the introduction of the " $\mathrm{Z}$ beam" (in which one mass was rigidly supported $25 \mathrm{~cm}$ above the beam, the other $20 \mathrm{~cm}$ below it), by Schweydar in 1926 (Heiland 1926) and the use of a circular beam in the "gradiometer", developed by the British physicists, Herman Shaw (1892-1950) and Ernest Lancaster-Jones (?d. 1945) in 1927. In the latter, a thin circular beam, suspended from torsion wire at its centre, formed the circumference of a $20 \mathrm{~cm}$ radius circle. It was provided with two masses in the plane of the beam, counterbalanced by a third mass mounted on a thin $50 \mathrm{~cm}$ rod whose base was attached to the beam; the centres of all three masses being $120^{\circ}$ apart in the plane of the beam. This arrangement was sensitive to gradient, but eliminated the effects of curvature (Shaw and Lancaster Jones 1929; Lancaster-Jones 1932). Both instruments were smaller and more portable, as well as faster to use, than the traditional torsion balance (both were about half the height of a typical torsion balance and weighed about 50 and $30 \mathrm{~kg}$ respectively). The gradiometer was tested extensively in Australia during the 1928-30 Imperial Geophysical Experimental Survey (Broughton Edge and Laby 1931) and was found to perform reliably.

By 1926 the torsion balance had become largely discredited as a primary reconnaissance tool (Barton 1930b) although it was often used in combination with seismic surveys to locate salt domes (Elbof Geophysical 1927, pp. 32-38; McClintock 
Figure 13. Number of torsion balance and gravimeter parties operating on the GulfCoast of Texas (GC) and in the whole of the United States (US) from Q3 1934 to Q2 1947. The downturn following the end of World War II is attributable to the increasing success of seismic methods of prospecting. Data source: Eckhardt (1949, Figs. 1 and 2).

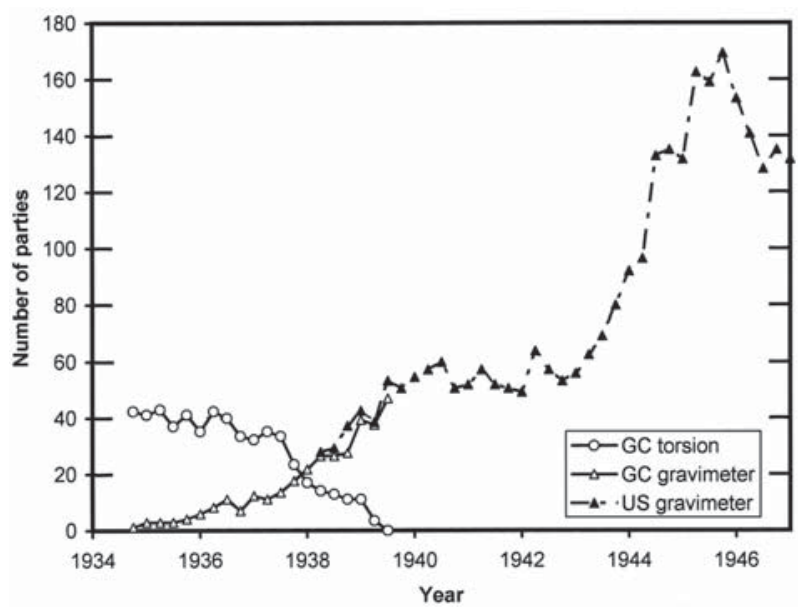

and Phemister 1927; Barton 1929, 1930a; Sineriz 1928; Numerov 1930; Heiland 1940, Figs. 7-105 to 7-113,pp. 275-282). Alexanian(1932,pp. 172-174) mentions exploration for diamond-bearing peridotite at Murfreesboro, Arkansas, USA; for lead and zinc in the Tri-State district, USA; and for iron at Hanbürgel, Siegerland, Germany; Numerov (1930) mentions searching for coal and oil in Russia.

\section{Arrival of the gravity meter}

In 1930 the Shell, Amerada (Rycade) and Continental Oil companys all ceased using the torsion balance in favour of a new, and far more sensitive, instrument-the gravity meter, also called the gravimeter. Although in 1930 the Gulf Oil and Development Company replaced use of the torsion balance with their own, very sensitive, pendulum apparatus, which they had developed in 1929 and continued to use until 1936 (Gay 1940, Eckhardt 1949; Heiskanen and Vening Meinesz 1958, Figure 4-4; Lenzen and Multhauf 1965, Figures 28, 29), by 1932, Gulf too had begun work on designing their own gravimeter and it entered regular service in 1935 (Eckhardt 1949). By 1940 the transition was complete (Figure 13).

The term gravimeter to denote an instrument for the measurement of gravity, may have been introduced by the English army officer, geodesist and astronomer, Colonel John Herschel (1837-1921) in his publications on the torsion balance in 1880 and 1881 . The concept of an "apparatus" for the measurement of gravity based on measurement of the elongation of a spring had been earlier proposed by his father, the astronomer Sir John Frederick William Hershel (1792-1871) in 1833 (p. 145), but the technology of the time never enabled a working instrument to be made, and there is no evidence that his father's proposal influenced subsequent developments.

Nevertheless, the first members of this new breed of instruments depended on extremely accurate measurement of the gravity-induced displacement of a mass, counterbalanced by the restoring force of a spring. These new gravity meters (Figure 14) enabled measurement of changes in the force of gravity to $0.1 \mathrm{mGal}$ or less (see Heiskanen and Vening Meinesz 1958, pp. 104-115; Bomford 1971, pp. 424-433; Telford and others 1976, pp. 36-50; Harrison 1984; Chapin 1998; Nabighian and others 2005 for description of the various types). But, like the torsion balance, they were relative instruments, they too needed to be tied-in to stations where the absolute value of gravity had been measured 


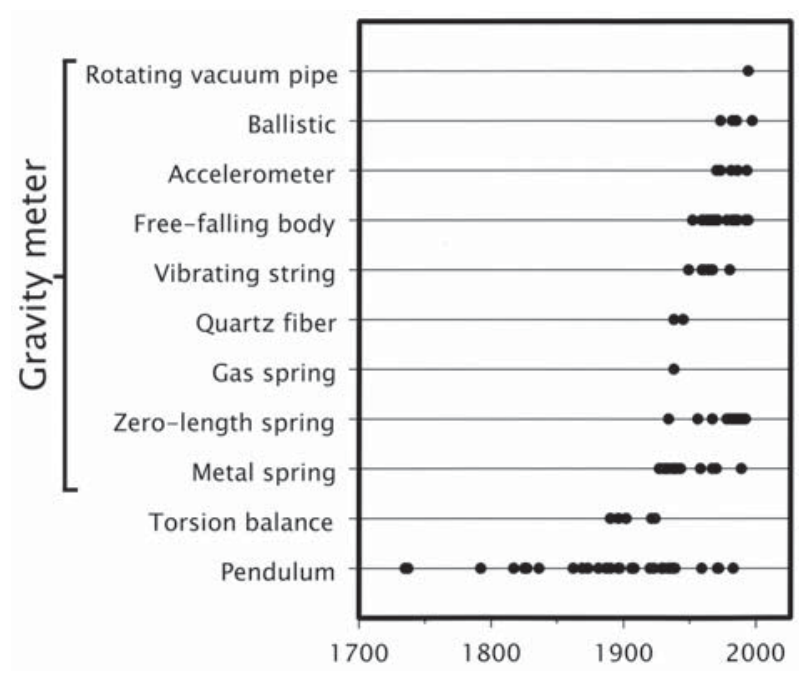

Figure 14. Dotplot of the dates of introduction of various models of pendulum, torsion balance and types of gravity meter (data from Lenzen and Multhauf 1965, Chapin 1998 and Nabighian and others 2005; see references therein for further details).

(McCollum and Brown, 1943). Much smaller and lighter than the torsion balance, they were more attractive for use in the field, as well as being far more sensitive. Furthermore

[t]he secrecy with which a survey can be made may be of importance: the little white torsion-balance houses which have to stand for 4 to 8 hours on a station are most conspicuous; but a gravimeter which works in an ordinary light delivery truck, and which requires from 5 to 10 minutes for the occupation of a station, can work along roads almost wholly unnoticed. (Barton 1938a, p. 326).

Nettleton (1940, Figure 22, p. 39) shows gravimeter being used inside a truck, and Eve and Keys (1954, Figure 113, p.244) in a car.

The Geophysical Research Division of the Gulf Oil Company began development of the Gulf gravimeter in late 1932 and it was deployed in 1935 (Eckhardt 1949). By 1940, 400,000 stations had been occupied (in some instances finding one salt dome a week), at a much lower cost than was possible with seismic surveying. By 1939, there were at least six types of gravity meter in general use on the Gulf Coast. Nevertheless, in the previous year, Barton was of the opinion that

[t]he pendulum and gravimeter will supplement, but will never replace, the torsion balance as the mainstay of gravitational prospecting under the more skilled interpreters .... the gradient gives a sharper picture of certain types of structure than does relative gravity; and the differential curvature is particularly valuable in the interpretation of certain structural features; but many interpreters who specialise in gravitational prospecting are not competent to use the differential curvature. (Barton 1938a, p. 323).

Improved versions of the gravity meters first used in the 1930s still form the basis for modern survey work. One of the most important developments was that by the American physicists, Lucien J.B. LaCoste, Jr. (1908-1995) and Arnold Romberg (18821974) of the inclined "zero-length" spring gravimeter, based on a principle discovered by LaCoste, in 1932, when both were on the faculty of the University of Texas, Austin (LaCoste 1934, 1988). A zero-length spring is pre-stressed and wound in such a way that its elongation is equal to that between the points to which it is attached; when no mass is applied, it behaves as though it has no physical length. The extension of an inclined zerolength spring, attached to a lever-arm at the arm's centre of gravity adjacent to the test 
mass at its outside end, under the force of gravity provides an extremely sensitive measuring device (accurate to about $0.035 \mathrm{mGal}$; Harrison 1984).

The LaCoste-Romberg gravity meter did not come into commercial production until the late 1930s. In 1946, they developed a successful instrument for ship-borne gravity work and this was followed by an air-borne gravity meter, first tested in 1958 (LaCoste 1967, Thomson and LaCoste 1960). By 1963, it was being tested in helicopters, which offered a more stable flight platform, but it was not until 1970 that systems suitable for the oil and mining industries began to be developed and the first commercial surveys were undertaken in 1979 (Gumbert 1998).

Gravity gradiometry began to come back into fashion in the late 1970s and has begun to be extensively used since 1990, as it has been realised that it is particularly well-suited for use from moving platforms, such as ships and aircraft. As Barton pointed out, it is proving particularly useful for fault- and edge-detection and to assist structural interpretation, as well as in mineral exploration (see Pawlowski 1998).

\section{CONCLUSIONS}

The first systematic measurements of the force of Earth's gravity field in the eighteenth century began as an essentially geodetic exercise, with the aim of providing an alternative, and perhaps more precise, route to defining the Figure of the Earth than that provided by arc-length measurements. This was accompanied by a keen interest in obtaining a value for the mean density of the Earth. By the mid-nineteenth century, the increasing number of stations at which the pendulum was swung began to provide the first evidence that geological factors might account for the observed discrepancies between the force of gravity at a station (corrected for observational conditions and height of the station above sea level) and that predicted by the model that it was simply proportional to $\sin ^{2}$ (latitude). The discovery of large negative Bouguer gravity anomalies associated with the mountain chains of the Himalayas in India and, later, the Rocky Mountains in North America, led to development of the Pratt and Airy compensation models and to the concept of isostasy. Despite improvements in pendulum technology, and the introduction of the torsion balance by Eötvös in the 1890s, it was not until the 1920s that the application of gravity surveys to the search for oil fields and mineral deposits began to be widespread. The introduction of the gravity meter in the 1930s produced a tool which was fast to use and easy to conceal compared to the torsion balance, and a new era of commercial exploitation began. However, use of the gravity meter as a tool for oil exploration gradually fell out of favour, as a result of increasingly successful competition from refraction seismic surveys, introduced in the early 1920 s with the later development of fan- and arc-shooting methods. During the 1930s and early 1940s, this was replaced by the even-more effective reflection seismic methods. However, with the development of progressively more sensitive instruments, the gravity meter has regained its place, becoming an essential companion to 3-D seismic surveys and, with new instrumentation, gradiometry has seen a revival as an extremely powerful exploration tool (Nabighian and others 2005).

\section{ACKNOWLEDGEMENTS}

The referees are thanked for their comments and, in one case, provision of some useful references. 


\section{REFERENCES}

Ádám, József. 2000. Geodesy in Hungary and the relation to IAG around the turn of the 19th/20th Century - A Historical Review. http://www.gfy.ku.dk/ iag/HB2000/part1/historic.htm, 1-10.

Airy, George B. 1855. On the Computation of the Effect of the Attraction of Mountain-masses, as disturbing the Apparent Astronomical Latitude of Stations in Geodetic Surveys. Philosophical Transactions of the Royal Society of London 145: 101-104.

Airy, George B. 1856a. Account of Pendulum Experiments undertaken in the Harton Colliery, for the purpose of determining the Mean Density of the Earth. Philosophical Transactions of the Royal Society of London 146: 297-342.

Airy, George B. 1856b. Supplement to the "Account of Pendulum Experiments undertaken in the Harton Colliery;" being an Account of Experiments undertaken to determine the Correction for the Temperature of the Pendulum. Philosophical Transactions of the Royal Society of London 146: 343-355.

Alexanian, C.L. 1932. Traité Practique de Prospection Géophysique a l'usage des géologues et des ingénieurs des mines. Paris: Ch. Béranger.

Ambronn, Richard, 1928. Elements of geophysics as applied to explorations for minerals, oil and gas. Translated by Margaret C. Cobb. New York: McGraw-Hill.

Anonymous, 1862. M. Perrot soumet au jugement de l'Académie les principes de deux appareils destinés à rendre manifestes et mesurables les variations occasionées dans l'intensité et la direction de la pesanteur à la surface de la terre, par les divers mouvements de notre globe et l'attractions des corps célestes. Comptes Rendus Hebdomadaires des Séances de l'Académie des Sciences 54: 728-729, 851-852.

Babinet, Jacques, 1863. Appareil pour la mesure statique de la pesanteur. Comptes Rendus Hebdomadaires des Séances de l'Académie des Sciences 56: 244-248.

Barrell, Joseph, 1914. The strength of the Earth's crust. II. Regional distribution of isostatic compensation. Journal of Geology 22: 145-165.

Barton, Donald C. 1929. The Eötvös torsion balance method of mapping geologic structure. In: Geophysical Prospecting. Papers and Discussions Presented at meetings Held in New York, February, 1928, and at Boston, August, 1928. 416-479. New York, NY: American Institute of Mining and Metallurgical Engineers.

Barton, Donald C. 1930a. Geophysical prospecting for oil. Bulletin of the American Association of Petroleum Geologists 14: 201-226.

Barton, Donald C. 1930b. Review of Geophysical Prospecting for Petroleum, 1929. Bulletin of the American Association of Petroleum Geologists 14: 1105-1127.

Barton, Donald C. 1938a. Petroleum Geophysics. In The Science of Petroleum, Albert E. Dunstan, A.W. Nash, Benjamin T. Brooks and Sir Henry Tizard (eds). Volume 1.319-327. London: Oxford University Press.

Barton, Donald C. 1938b. Gravitational Methods of Prospecting. In The Science of Petroleum, Albert E. Dunstan, A.W. Nash, Benjamin T. Brooks and Sir Henry Tizard (eds). Volume 1. 364-381. London: Oxford University Press.

Barton, Donald C., Ritz, C.H. \& Hickey, Maude. 1933. Gulf Coast geosyncline. Bulletin of the American Association of Petroleum Geologists 17: 1446-1458.

Born, A. 1923. Isostasie und Schweremessung. Ihre bedeutung für geologische vorgänge. Berlin: Julius Springer.

Bomford, Guy, 1971. Geodesy. Third edition. Oxford: Clarendon Press.

Bouguer, Pierre, 1749. La Figure de la terre, Déterminée par les observations de Messieurs Bouguer et de la Condamine, de l'Académie Royale des Sciences, envoyés par ordre du Roy au Pérou pour observer aux environs de l'équateur. Avec une Relation abregée de ce Voyage, qui contient la description du Pays dans lequel les Opérations ont été faites, par M. Bouguer. Paris: Charles-Antoine. Jombert.

Bowie, William, 1912a. Some Relations between Gravity Anomalies and the Geologic Formation in the United States. American Journal of Science, series 4, 33: 237-240.

Bowie, William, 1912b. Effect of topography and isostatic compensation upon the intensity of gravity. U.S. Coast and Geodetic Survey. Special Publication 12. Washington: Government Printing Office.

Bowie, William, 1917. Investigations of Gravity and Isostasy. U.S. Coast and Geodetic Survey. Special Publication 40. Washington: Government Printing Office.

Broughton Edge, Arthur B. and Laby, Thomas H. (eds), 1931. The principles and practice of geophysical prospecting being the report of the Imperial Geophysical Experimental Survey. Cambridge: Cambridge University Press.

Broun, John A. 1863. Lettre de M. Broun sur un appareil de son invention pour la mesure statique de la 
pesanteur. Comptes Rendus Hebdomadaires des Séances de l'Académie des Sciences 56: 1135-1137. Bruins, Gerard J. and Scholte, J.G.J. 1967. Felix Andries Vening Meinesz. Bibliographical Memoirs of Fellows of the Royal Society 13: 294-308.

Brush, Stephen G. 1979. Nineteenth-Century debates about the Inside of the Earth: Solid, Liquid or Gas? Annals of Science 36: 225-254.

Bullen, Keith E. 1975. The Earth's Density. London: Chapman and Hall.

Burrard, Sidney G. 1905. An account of the Scientific work of the Survey of India, and a comparison of its progress with that of foreign surveys. Professional Paper, Survey of India 9: 1-23.

Burrard, Sidney G. 1920. A Brief Review of the Evidence upon Which the Theory of Isostasy Has Been Based. The Geographical Journal 56: 47-52.

Cajori, Florian (ed.), 1934. Sir Isaac Newton's Mathematical Principles of Natural Philosophy. Volume II, Book III. The System of the World. Third. edition. Translated from the original Latin [by] Andrew Motte, 1729. London: The Royal Society [reprinted 1962, Berkley, CA: University of California Press].

Cavendish, Henry, 1798. Experiments to Determine the Density of the Earth. Philosophical Transactions of the Royal Society of London 88: 469-526.

Chapin, David, 1998. Gravity instruments: Past, present, future. The Leading Edge 17: 100-112.

Clarke, Alexander R. 1866. Comparisons of the standards of length of England, France, Belgium, Prussia, Russia, India, Australia, made at the Ordnance Survey office, Southampton ... under the direction of Col. Sir Henry James. London: G. E. Eyre and W. Spottiswoode.

Couchman, Harold J. 1915. The pendulum operations in India and Burma. 1908 to 1913. Survey of India, Professional Paper 15: 1-190.

Coulomb, Charles Augustin, 1788. Premier Mémoire sur l'Électricité et le Magnétisme. Construction et usage d'une Balance électrique, fond e sur le propriété qu'ont les Fils de métal, d'avoir une force de réaction de Torsion proportionnnelle à l'angle de Torsion. Détermination expérimentale de la loi suivant laquelle les élémens des Corps électrisés du méme genre d'Électricité, se repoussent mutuellement. Histoire de l'Académie Royale des Sciences 1788 [for 1785]: 569-577.

Crosthwait, Harold L. 1912. Investigation of the theory of isostasy in India. Survey of India, Professional Paper 13: 1-14.

Dana, James D. 1875. Manual of Geology: Treating of the Principles of the Science with Special Reference to American Geological History. Second edition. New York: Ivison, Blakeman, Taylor and Co.

de Böckh, Hugo [edited by Boswell, Percy G.H.], 1934. Gravity Measurements in the Great Hungarian Plain. Journal of the Institution of Petroleum Technologists 20: 884-890.

Dutton, Clarence E. 1889. On some of the greater problems of physical geology. Bulletin of the Washington Philosophical Society series B, 11: 51-64.

Eckhardt, Engelhardt A. 1949. A brief history of the gravity method of prospecting for oil. In: Lewis L. Nettleton (ed.) Geophysical Case Histories. Volume I. 21-32. Houston: Society of Exploration Geophysicists.

Elbof Geophysical. 1927. The discovery and investigation of mineral deposits by geophysical methods. Kassel: Elbof Geophysical Co.

Eötvös, Roland, 1896. Untersuchungen über Gravitation und Erdmagnetismus. Wiedemann's Annalen der Physik und Chemie, Neue Folge 59: 354-400.

Eötvös, Roland,1908. Bestimmung der Gradienten der Schwerkraft und ihrer Niveauflächen mit Hilfe der Drewaage. Verhandlungen der XV Allgemeinen Conferenz der Internationalen Erdmessung, zu Budapest 1906, 1: 337-395. Berlin: Reimer.

Eötvös, Roland,1910. Bericht über geodätische Arbeiten in Ungam besonders über Beobachtungen mit Drehwaage. Verhandlungen der XVI Allgemeinen Conferenz der Internationalen Erdmessung, zu London und Cambridge 1909, 1: 319-350. Berlin: Reimer.

Eötvös, Roland,1913. Bericht über Arbeiten mit der Drehwaage ausgeführt im Auftrage der kön. Ungarischen Regierung in den Jahren 1908-1911. Verhandlungen der XVII Allgemeinen Conferenz der Internationalen Erdmessung, zu Hamburg 1912, 1: 427-438. Berlin: Reimer.

Evans, James, 1996. Fraud and illusion in the anti-Newtonian rear-guard: the Coultaud-Mercier affair and Bertier's experiments, 1767-1777. Isis 87, 74-107.

Evans, Percy and Crompton, Wilfred, 1946. Geological factors in gravity interpretation illustrated by evidence from India and Burma. Quarterly Journal of the Geological Society of London 102: 211-249.

Eve, Arthur S. and Keys, David A. 1954. Applied geophysics in the search for minerals. Fourth edition. Cambridge: Cambridge University Press.

Faye, Hervé A. 1880. Sur la réduction des observations du pendule au niveau de la mer. Comptes Rendus 
Hebdomadaires des Séances de l'Académie des Sciences 86: 1443-1446.

Ferrier, Ronald W., 1982. The History of the British Petroleum Company. I. The developing years 1901-1932. Cambridge: Cambridge University Press.

Gay, Malcolm W. 1940. Relative Gravity measurements Using Precision pendulum Equipment. Geophysics 5: 176-191.

Glennie, Edward A. 1932. Gravity anomalies and the structure of the Earth's crust. Survey of India, Professional Paper 27: 1-35.

Gore, James H. 1903. A bibliography of geodesy. Second edition. Appendix 8. 427-787. Report of the Superintendent of the Coast and Geodetic Survey showing the progress of the work from July 1, 1901, to June 30, 1902. Washington: Government Printing Office.

Gulatee, B.L. 1956. Gravity anomalies over Pre-Cambrian formations in peninsula India. Survey of India, Technical Paper 11, 1-12.

Gumbert, William R. 1998. An historical review of airborne gravity. The Leading Edge 17: 113-116.

Haasemann, Ludwig, 1905. Bestimmung der Intensität der Schwerkraft auf 66 Stationen im Harz und seiner weiteren Umgebung. Veröffentlichung des Königlichen Preuszischen Geodätischen Institutes neue folge 19. Berlin: Stankiewicz.

Halbouty, Michael T. 1967. Salt Domes. Gulf Region, United States and Mexico. Houston: Gulf.

Halley, Edmund, 1692. An Account of the Cause of the Change of the variation of the Magnetical Needle; With an Hypothesis of the Structure of the Internal parts of the Earth: As it was Proposed to the Royal Society in One of their Late Meetings. Philosophical Transactions of the Royal Society of London 16: 563-578.

Harrison, J. Christopher, 1984. Techniques for measuring gravity on or close to the Earth's surface. In Guidance and Control Conference, Seattle WA, August 20-22, 1984. Technical Papers (A84-43401 2163). 258-263. New York: American Institute of Aeronautics and Astronautics.

Hayford, John F. 1911. The relations of isostasy to geodesy, geophysics and geology. Science, new series 33: 199-208.

Hayford, John F. and Bowie, William, 1912. The effect of topography and isostatic compensation upon the density of gravity. U.S. Department of Commerce and Labor, Coast and Geodetic Survey, Special Publication 10, 1-132.

Heiland, Carl A. 1926. Schweydar-Bamberg types of Eötvös Torsion balance. Bulletin of the American Association of Petroleum Geologists 10: 1201-1209.

Heiland, Carl A. 1940. Geophysical Exploration. New York: Prentice-Hall.

Heiskanen, Weikko A. 1931. Isostatic tables on the basis of Airy's hypothesis. Bulletiné géod sique 30, 110

Heiskanen, Weikko A. and Vening Meinesz, Felix A. 1958. The Earth and its Gravity Field. New York: McGraw-Hill.

Helmert, Friedrich R. 1884. Die mathematischen und physikalischen Theorieen der höheren Geodäsie: Zweiter Theil: Die physikalischen Theorieen, mit Untersuchungen über die mathematische Erdgestalt auf Grund der Beobachtungen. Leipzig: B.G. Teubner [reprinted 1962].

Helmert, Friedrich R. 1901. Der normale Theil der Schwerkraft im Meeresniveau. Sitzungsberichte der Königlich Preussischen Akademie der Wissenschaften zu Berlin. Physikalischmathematische Classe 14: 328-336.

Herschel, John, 1880. On a Simplified Form of the Torsion-Gravimeters of Broun and Babinet. Proceedings of the Royal Society of London 31: 141-146.

Herschel, John, 1881. On gravimeters, with special reference to the Torsion-Gravimeter Designed by the late J. Allan Broun, F.R.S. Proceedings of the Royal Society of London 31: 317-320.

Herschel, John F.W. 1833. A Treatise of Astronomy. London: Printed for Longman, Rees, Orme, Brown, Green and Longman: John Taylor.

Howarth, Richard J. 2007. Gravity surveying in early geophysics. I. From time-keeping to the Figure of the Earth. Earth Sciences History 26:201-228.

Howse, Derek, 1990. Neville Maskelyne. The Seaman's Astronomer. Cambridge: Cambridge University Press.

Hutton, Charles, 1779 [read 1778]. An Account of the Calculations made from the Survey and Measures taken at Schehallien, in order to ascertain the mean Density of the Earth. Philosophical Transactions of the Royal Society of London 68: 689-788.

Jakosky, Jay J. 1940. Exploration geophysics. Los Angeles: Times-Mirror.

Keay, John, 2000. The Great Arc. The dramatic tale of how India was mapped and Everest was named. London: HarperCollins.

Kushner, David S. 1990. The emergence of geophysics in nineteenth century Britain. Ph.D. dissertation, Princeton University [available from UMI, Ann Arbor, MI; order no. 9104334]. 
Kushner, David S. 1993. Sir George Darwin and a British School of Geophysics. Osiris 8: 196-224.

LaCoste, Lucien J.B. 1934. A New Type Long period Seismograph. Physics 5:178-180.

LaCoste, Lucien J.B. 1967. Measurement of gravity at sea and in the air. Review of Geophysics 5: 477-256.

LaCoste, Lucien J.B. 1988. The Zero-length Spring Gravity Meter. Geophysics 7: 20-21.

Lancaster-Jones, Ernest, 1932. The principles and practice of the gravity gradiometer. Journal of Scientific Instruments 9: 341-353, 373-380.

Lenzen, Victor F. and Multhauf, Robert, P. 1965. Development of Gravity Pendulums in the 19th Century. Contributions from the Museum of History and Technology: Paper 44. United States National Museum Bulletin 240: 301-347.

Leroy, Jean-Baptiste, 1776. Discours sur l'attraction des montagnes, prononcé dans l'assemblée annuelle de la Société Royale de Londres du 30 novembre 1775 par le Président M. le Chevalier Baronet Pringle .... Traduit par M. Le Roy. Observations sur la Physique 1776, 418-434.

Maskelyne, Neville, 1775a [read 1772]. A proposal for measuring the Attraction of some Hill in this Kingdom by Astronomical Observations. Philosophical Transactions of the Royal Society of London 65: 495-499.

Maskelyne, Neville, 1775b. An Account of observations made on the Mountain Schehallien for finding its Attraction. Philosophical Transactions of the Royal Society of London 65: 500-542.

McCollum, Elmer V. and Brown, Andrew, 1943. The Use of the Gravity meter in Establishment of Gravity Bench Marks. Geophysics 8: 379-390.

Mendenhall, Thomas C. 1895. On the relation of gravity to continental elevation. American Journal of Science Third series, 49: 81-86.

Nabighian, Misac N., Ander, M.E., Grauch, V.J.S., Hansen, R.O., LaFehr, T.R., Li, Y., Pearson, W.C., Peirce, J.W., Phillips, J.D., and Ruder, M.E. 2005. Historical development of the gravity method in exploration. Geophysics 70: 63ND-89ND.

Nettleton, Lewis L. 1940. Geophysical prospecting for oil. New York: McGraw-Hill.

Newton, Isaac, 1726. Mathematical Principles of Natural Philosophy. Vol. II, Book III. The System of the World. Third edition. Translated from the original Latin [by] Andrew Motte, 1729. The Royal Society, London. Revised, 1934, with additional notes by Florian Cajori, 397-680 [reprinted 1962, Berkley, CA: University of California Press].

Numerov, Boris. 1930. Geophysical methods of prospecting in the Union of Socialist Soviet Republics. Bulletin of the American Association of Petroleum Geologists 14: 93-98.

Pawlowski, Bob. 1998. Gravity gradiometry in resource exploration. The Leading Edge 17: 51-52.

Pekár, Dezsö, 1928. Die Entwicklung der Eötvösschen Originaldrehwagen. Naturwissenschaften16: 10791088.

Playfair, John, 1811. Account of a Lithological Survey of Schehallien, made in order to determine the specific gravity of the Rocks which compose that Mountain. Philosophical Transactions of the Royal Society of London 51: 347-377.

Playfair, John, 1812. Of the solids of greatest attraction, or those which, among all the solids that have certain properties, attract with the greatest force in a given direction. Transactions of the Royal Society of Edinburgh 6: 187-243.

Poynting, John H. 1894. The mean density of the Earth. An essay to which the Adams Prize was adjudged in 1893 in the University of Cambridge. London: Griffin.

Pratt, John H. 1836. The mathematical principles of mechanical philosophy: and their application to the theory of universal gravitation. Cambridge: J. and J.J. Deighton.

Pratt, John H. 1855. On the Attraction of the Himalaya Mountains and of the elevated regions beyond them, upon the Plumb-line in India. Philosophical Transactions of the Royal Society of London 145: 53-100.

Pratt, John H. 1859. On the Deflection of the Plumb-line in India, caused by the Attraction of the Himalaya Mountains and of the elevated regions beyond; and by its modification by the compensating effect of a Deficiency of Matter below the Mountain Mass. Philosophical Transactions of the Royal Society of London series B, 149: 745-778.

Pratt, W.E. 1939. Donald Clinton Barton (1889-1939). Bulletin of the American Association of Petroleum Geologists 23: 1888-1896.

Putnam, George R. 1895a [for 1894] Appendix no.1. Relative determinations of gravity with half-second pendulums, and other pendulum investigations. Report of the Superintendent of the U.S. Coast and Geodetic Survey showing The Progress of the Work during the Fiscal Year ending with June, 1984. In two parts. Part II. Appendices relating to the methods, discussions, and results of the Coast and Geodetic Survey. 5-55. Washington: Government Printing Office.

Putnam, George R. 1895b. Results of a Transcontinental series of gravity measurements. Bulletin, Philosophical 
Society of Washington 13: 31-60.

Robertson, Herbert, 2000. A historic correspondence regarding the introduction of the torsion balance to the United States. The Leading Edge 19: 652-654.

Rybar, Stephen, 1923. The Eötvös torsion balance and its application to the finding of mineral deposits. Economic Geology 18: 639-662.

Schweydar, Wilhelm K. 1918. Die bedeutung der drehwage von Eötvös fur die geologische forschnung nebst mitteilung der ergbnisse einiger messungen. Zeitschrift fur praktische Geologie 26: 157-162.

Shaw, Eugene W. 1917. Possibility of Using Gravity Anomalies in the Search for Salt Dome Oil and Gas Pools. Science, new series 46: 553-556.

Shaw, Herman and Lancaster-Jones, Ernest, 1925. The Eötvös torsion balance and its application to the location of minerals. The Mining Magazine 32: 18-25, 86-92.

Shaw, Herman and Lancaster-Jones, Ernest, 1927. The Theory and Practical Employment of the Eötvös Torsion Balance. The Mining Magazine 36: 201-212, 274-282, 339-347; 37: 14-22 [reprinted 1927 as Locating Minerals and Petroleum; being a series of articles ... on the Theory and Practical use of the Eötvös Torsion Balance. London: L. Oertling].

Shaw, Herman and Lancaster-Jones, Ernest, 1929. The Gravity Gradiometer. The Mining Magazine 40: 272279.

Sineriz, J.Garcia, 1928. Los métodos geofisicos de Prospection. Boletin del Instituto Geologico y Minero de Espana 50: 1-498.

Stegena, Lajos, 1984. Hungarian contribution to the geophysical mapping of the world. In Contributions to the History of Geological Mapping, Endre Dudich (ed.). 251-255. Budapest: Akadémiai Kiadó.

Sterneck, Robert von, 1882. Untersuchungen über die Schwere im Innern der Erde, ausgeführt im Jahre 1882 in dem 1000 Meter tiefen Adalbert-Schachte des Silberbergwerkes zu Pribram in Böhmen. Mittheilungen des Kaiserlich-Königlichen Militär-Geographischen Institutes in Wien 2: 77-120.

Sterneck, Robert von, 1883. Wiederholung der Untersuchungen über die Schwere im Innern der Erde, ausgeführt im Jahre 1883 in dem 1000 Meter tiefen Adalbertschachte des Silberbergwerkes zu Pribram in Böhmen. Mittheilungen des Kaiserlich-Königlichen Militär-Geographischen Institutes in Wien 3: 59-94.

Sterneck, Robert von, 1885. Untersuchungen über die Schwere im Innern der Erde, ausgeführt im Jahre 1885 in dem Abrahamschachte des Silberbergwerkes "Himmelfahrtsfundgrube" bei Freiberg in Sachsen. Mittheilungen des Kaiserlich-Königlichen Militär-Geographischen Institutes in Wien 6: 1-23.

Sweet, George E. 1978. The History of Geophysical Prospecting. Third edition. Sudbury, Suffolk: Neville Spearman.

Telford, William M., Geldart, Lloyd P., Sheriff, Robert E. and Keys, David A. 1976. Applied Geophysics. Cambridge: Cambridge University Press.

Thomson, L. and LaCoste, L.J.B. 1960. Aerial Gravity Measurements. Journal of Geophysical Research 70: 5599-5613.

Thomson, William [Lord Kelvin], 1858. Improvements in Testing and Working Electric Telegraphs. U.K. Patent no. 329.

Vajk, Raoul, 1949. Baron Roland Eötvös. Geophysics 14: 6-9.

Veldkamp, Jan, 1984. History of Geophysical Research in The Netherlands and its former Overseas Territories. Amsterdam: North-Holland.

Vening Meinesz, Felix A. 1934. Gravity and the hypothesis of convection currents in the Earth. Verhandelingen van het koninklijk Nederlandse Akademie van Wetenschappen 37: 37-45.

Vening Meinesz, Felix A. 1941. Tables for regional and local isostatic reduction (Airy system) for gravity values. Delft: Waltman.

Volgyesi, Lajos, 2001. Geodetic applications of torsion balance measurements in Hungary. Reports on Geodesy, Warsaw University of Technology 57: 203-212.

von Oettingen, Arthur J. 1897 [for 1896]. Ueber die Nothwendigkeit und Nützlichkeit der Einführung von Einheiten für Geschwindigkeit und Beschleunigung. Verhandlungen der Gesellschaft Deutscher Naturforscher und Ärzte, 68. Versammlung zu Frankfurt am Mein, Zweiter Teil, Erste Hälfte. Leipzig: F.C.W. Vogel Verlag.

Washington, Henry S. 1922. Isostasy and rock density. Bulletin of the Geological Society of America 33: $375-$ 410.

Watts, Anthony B. 2001. Isostasy and Flexure of the Lithosphere. Cambridge: Cambridge University Press.

Weichert, E. 1897. Ueber die Massenvertheilung im Inneren der Erde. Nachrichten von der Königlichen Gesellschaft der Wissenschaften zu Göttingen. Mathematisch-physikalische Klasse. Heft 3, 221-243. 
Weiss, Oscar, 1935. Principles of the theory and practice of the Eötvös gravitational variometer (torsion balance) and the possibilities and limitations of its application in the Witwatersrand area. Journal of the Chemical, Metallurgical and Mining Society of South Africa 1935 (January): 1-52.

Williamson, Erskine D. and Adams, Leason H. 1923. Density distribution in the Earth. Journal of the Washington Academy of Sciences 13: 413-428.

Woodward, John, 1723. An essay towards a natural history of the earth, and terrestrial bodyes, especialy minerals: as also of the sea, rivers, and springs; with an account of the universal deluge, and of the effects that it had upon the earth. Third edition. London: A. Bettesworth and W. Taylor, R. Gosling, and J. Clarke. 
